\title{
'Custodiari' del tempo. Il corpo, il viaggio, il disegno
}

\author{
Claudio Patanè
}

Abstract

La percezione del viaggio oggi si è ridotta semplicemente, a una partenza ed a una destinazione finale. La logica del controllo da 'pacchetto turistico, tutto compreso! è prevalsa a discapito della vera essenza del viaggio nel quotidiano, il suo 'durante'. L'istantaneità fotografica e la compulsiva divulgazione nel web e nei social dei luoghi visitati, ha reso il viaggiatore distratto, smarrendo quel desiderio di scoperta, di lentezza, di ricordo e di narrazione in cui si viene coinvolti durante il viaggio e ritornando a casa. Consumare con lo sguardo e restituire attraverso il disegno, su di un diario, un volto, un luogo o una città che non conosciamo, significa diventare 'pausa' in un itinerario, per essere corpo narrante ricettivo di ciò che attraversiamo. L'avanzare, a piedi, con in mano un taccuino, fa mutare la percezione dello spazio, prima che il di/segno riveli, uno scorcio e più in là l'allargarsi ampio verso un paesaggio. La comunicazione proposta intende presentare alcune riflessioni a partire da esperienze personali narrate e rappresentate nei miei 'diari di viaggio', nel quotidiano e fuori da esso. Tali esperienze hanno evidenziato la necessità di proporzionare e contenere l'abbraccio di uno sguardo di un luogo, all'interno di una piccola 'custodia da viaggio', un diario appunto, fatto di pagine, inchiostro e quant'altro. Supporto di registrazione, conoscenza, accumulo di memorie, dispositivo sensoriale ed estensione del mio corpo errante.

Parole chiave

diario, disegno, analogico, viaggio, Mediterraneo.

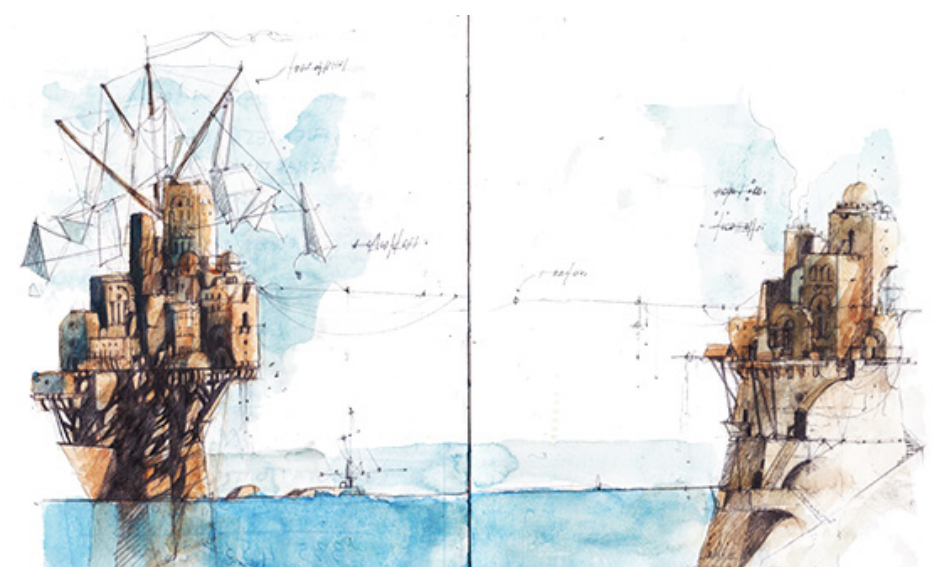


"Non è necessario che tu esca di casa.
Rimani al tuo tavolo e ascolta.
Non ascoltare neppure, aspetta soltanto.
Non aspettare neppure, resta
in perfetto silenzio e solitudine.
mondo ti si offrirà per essere smascherato,
non ne può fare a meno,
estasiato si torcerà davanti a te".

[Kafka 2004, p......]

Un ultimo grande disegno rappresenta un'architettura fatta di aquiloni in volo su di una spiaggia assolata. Un aquilone asimmetrico, fatto da tanti lacerti di carta colorata (a sua volta piccoli aquiloni), tenuti insieme da bacchette di legno, cavi, fili, nodi. Quasi fatica a librarsi in volo alzandosi appesantito, sfiorando la terra, a raso terra. Qualcuno ha detto che basterà equilibrarne il peso, ripartire i carichi riassestare l'asse attraverso contrappesi penduli, briglie e chiglie per farlo volare. Trascina dietro di sé, annodata una piccola casa, (cabina di pietra?). La sradica dalle sue fondamenta, dalla sua fissità, immobilità, dalla sua materia. Sullo sfondo un orizzonte fatto di mare, equoreo e in lontananza una barca a vela, o un veliero chissà, non se ne riconosce la dimensione tanto è lontana. Un paradosso è questo disegno (fig. I), un enigma, un rebus da cui svelarne il codice se si riesce, è un segreto. Ha un titolo questa scena: "Aquilone n2", e posto in calce un anagramma e la data, 2019 . Scrive John Berger:"Noi che disegniamo non lo facciamo solo per rendere visibile qualcosa agli altri, ma per accompagnare qualcosa di invisibile alla sua incalcolabile destinazione" [Berger 20।4, p. 176]. E il grande disegno "Aquilone n2" accompagna "qualcosa d'invisibile alla sua incalcolabile destinazione". Così come John Berger accompagna la sua amica Marie-Claude, alla sua "incalcolabile destinazione" la sua morte, ponendo all'interno della sua bara, un disegno di iris a pastelli colorati e saliva (così cancellava il filosofo, storyteller, compulsivo disegnatore), colti in forma grafica, per lei il giorno prima, dalla sua terrazza. In questo gesto Berger, consegna all'incalcolabile e invisibile destinazione il ritratto del fiore più amato e più bello dalla sua cara amica in vita, offrendo con generosità e tenerezza al buio ciò che non muore ma si "nasconde altrove, in un altro luogo" [Berger 2017, p. I32]. La bara diviene custodia eterna, di "ospiti al buio" [Berger 2017, p. 132]. per trattenere nell'ombra quell'altrove di ciò che è scomparso e scomparirà ma "in cui il futuro che è nostro e loro insieme $[. .$.$] azzerra il calcolo lineare del$ tempo" smentendone "la burocratica perentorietà" [Berger 20 I7, pp. I31, I32].

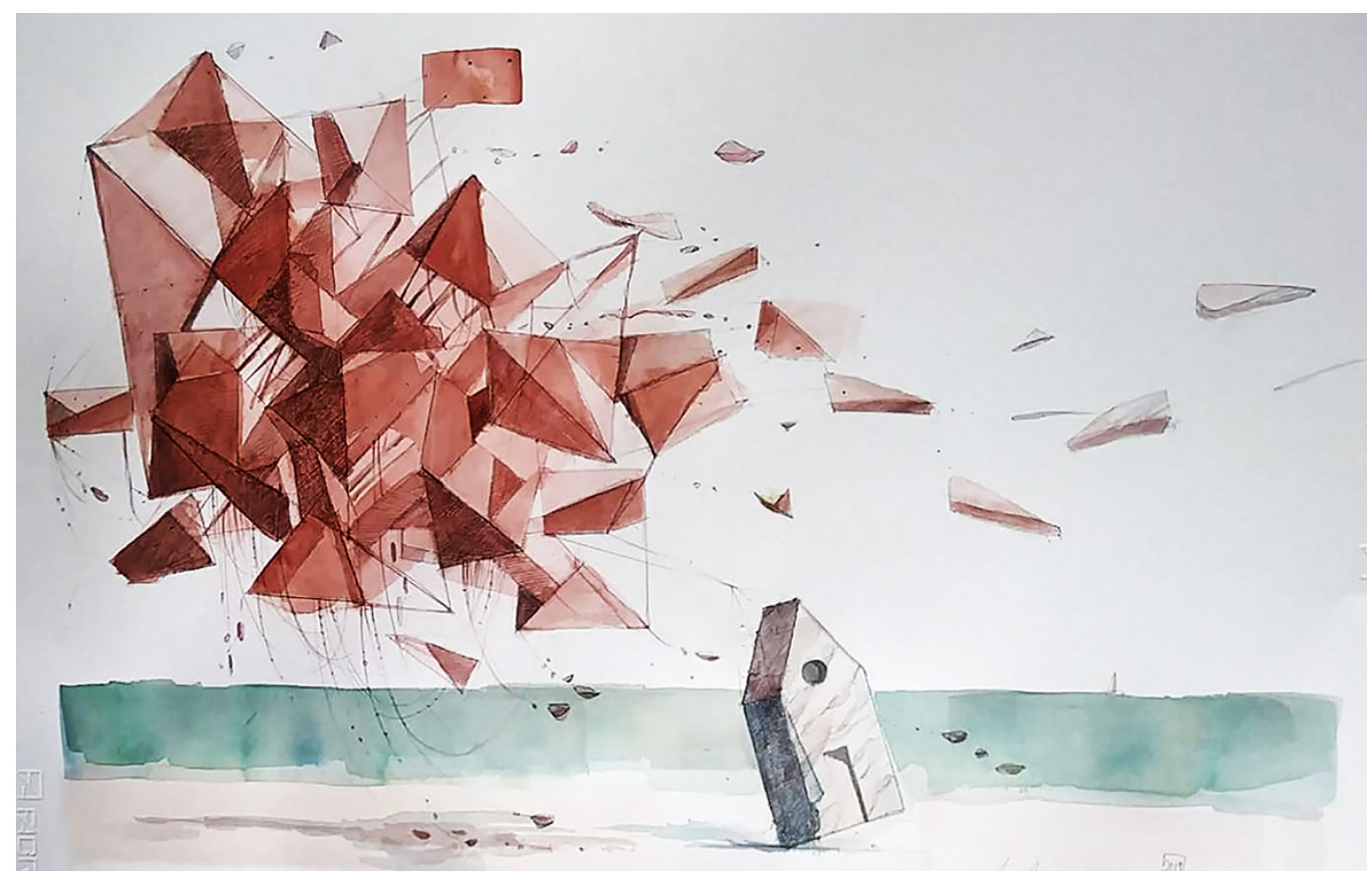


In questa volontà di celare, mantenere il segreto nel tempo, occultare, sta la riflessione che mi accingo a documentare, utilizzando come materiale di disamina i 'custodiari' disegnati e costruiti durante gli ultimi anni. Un resoconto di un viaggio, in cui il quotidiano e non solo, mediante l'opera di narrazione grafica, si dilata nel tempo, diviene immenso, in cui come scriverà Sant'Agostino: "il presente del presente si fa visione" [Agostino 2000, p. LIX-826]. II diario di viaggio, diventa 'custodiario di viaggio' (fig. 2), quando l'oggetto in sé si fa supporto cartaceo non solo per rappresentare la realtà, ma custodia per trattenere quell'"infraordinario" [Perec 1994] che sfugge alla quotidianità. In cui l'oggetto si fa 'manoscritto', suscettibile alle variazioni temporali, spaziali, dimensionali. La memoria si fa materia viva, che riempie con il suo corpo gli scaffali, produce polvere, tumefazione, escrescenza, sensibilità al deterioramento. La custodia protegge e conserva i resti di quel "laboratorio segreto" [Foti 20 I6] (fig. 3) in cui la pratica artistica, come esperienza, si fa pratica tangibile di disvelamento del quotidiano, della realtà che ci circonda e di conoscenza. II diario è un'entità piccola, discreta, che cela la rappresentazione del mondo per conservarla come cosa preziosa, segreta, tumulo e tomba, "per accompagnare qualcosa di invisibile alla sua incalcolabile destinazione" [Berger 20I4, p. 176]. Non si espone perché contenitore incompiuto, custode di aborti, tentativi, attese.

Fig. 2. Claudio Patanè, Diario di viaggio "Veneto" dell'autore, nelle pagine Torri e ruderi d'invenzione. acquerello e china su carta, 2017.

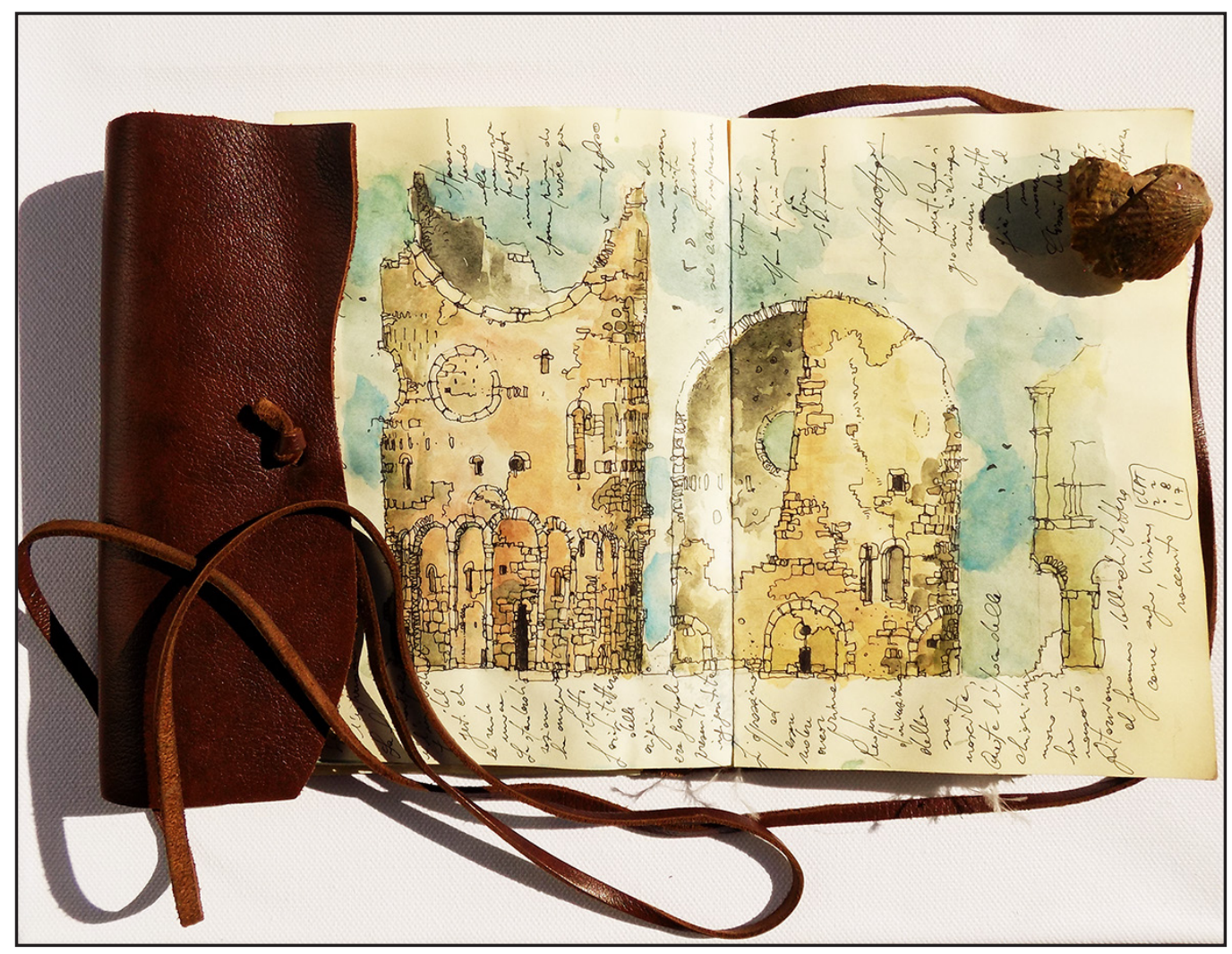

\section{II peso del corpo. II peso della carta. II peso del disegno}

Si inizia camminando, facendo esperienza del camminare come pratica consapevole dell'attraversamento, riconoscendosi parte attiva, viva, sensibile di un percorso. Lasciando traccia del proprio itinerario mediante le orme ri-calcate sulla terra. Un percorso che invita anche alla deriva [Debord 1956] perdendosi, restando al tempo, al passo del mondo. In seguito il solo passo non basta più, si sente la necessità di fare del percorso un racconto, rendendo 
tangibili le cose viste, scandendo il tempo mediante pause, in cui viene scelto un luogo dove sedersi, sostare, 'consumare' con lo sguardo e rappresentarlo su di un taccuino. Una bulimia compulsiva nel trattenere oggetti, cose naturali, frammenti reali di luoghi, di panorami, di città attraversate, del mondo intero interiorizzato, filtrato dal corpo, dagli occhi della mente. È il disegno libero, a mano libera, la più antica forma spirituale di narrazione, anarchica, incompiuta, infinita, viva (fig. 4). La scelta di un luogo geografico dove posizionarsi reagendo all'atmosfera, irradiandosi allo spazio, rilevandone le essenze, presenze, altre temporalità. "Pausare" divenendo il fermarsi stesso cammino, attivo, conturbante. "lo, che procedevo alla cieca, ho condotto me stesso a vedere. Ho visto. E sono rimasto stupito e incantato da ciò che ho visto, e ho desiderato di identificarmici" [Edwards 2002, p. 276]. L'atto del disegnare dal vero ci permette di identificarci con il soggetto/oggetto/paesaggio ritratto divenendone parte viva, con-fondendoci con esso assimilandone dimensioni, immergendoci in materie, colori, tessiture, movimenti, ombre, passaggi di tempo. La scrittura eccessiva iniziale, cede il passo all'appunto grafico, illustrato, alla sovrapposizione di segni, che non conosce direzione,

Fig. 3. Claudio Patanè, Diario di viaggio "Veneto" dell'autore, nelle pagine Campionature del mare, acquerello, matita e china su carta, 2017.

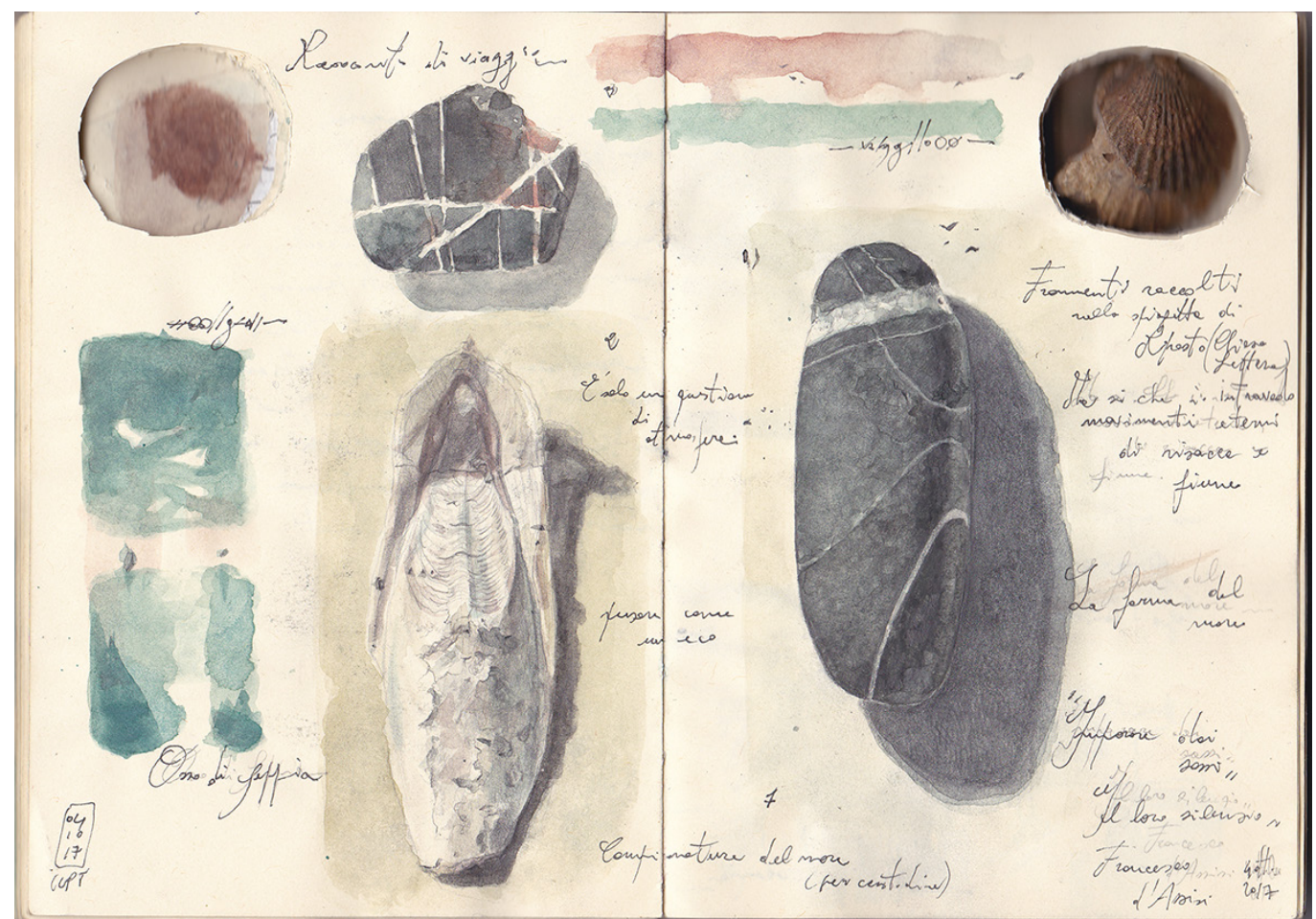

verso, struttura come nella scrittura. II disegno libero, segue le regole del sistema di prossimità e relazione tra linee, punti e superfici, coglie l'enigma della profondità, identificando nella processualità del gesto e nella pressione della mano una sovrapposizione di inesattezze che smussate, distillate, corrette, proporzionate stabiliscono un'armonia tra segni, colature e il resto della superficie bianca, increspata del foglio di carta (fig. 5). II disegno a sole linee e acqua colorata, povero, fragile non diviene così icona o simulacro, non immortala come in fotografia, ma genera vita [Berger 2017, p. I86] perché la sua tensione permette di identificarsi con la temporalità e processo che lo realizza, sfuggendo alle leggi dell'apparenza. II disegno del mondo 'grava' sul foglio ma privo di peso. Come nel disegno di architettura o di una città si rinuncia alla legge di gravità e alla sua costruzione reale e statica. Scriverà Ugo Rosa in tal senso nel disegno di architettura nell'opera di Mario Ridolfi: "il disegno è, insomma, il mestruo degli architetti: naturalmente in questi casi, purtroppo sempre più rari, in cui non ne è la gonorrea. Attraverso il disegno l'architettura assolve se stessa dalla costruzione 
e dalla gravità della legge, rinunzia alla nascita e viene espulsa, già in qualche modo "finita" ma tuttavia ancora oscuramente palpitante, satura di promesse. Non c'è architetto, più di Mario Ridolfi, in cui il disegno mostri con maggiore evidenza questa caratteristica mestruale, di spurgo oscuro e sanguigno, di scoria che già la morte adombra e che, pure, rimane inconfondibilmente pulsante, misteriosamente vitale" [Rosa 2002, p. I]. Suonano scomode queste parole, in un'epoca, in cui la perdita di lucidità nei confronti dell'esperienza del disegno del reale a favore del l'esperienza del disegno virtuale, massmediale e dell'assenza ha reso e avantaggiato quelle lobby e servi della tecnologia capitalistica, rendendo standardizzante, vuota, uguale a sè stessa, stanca e annoiata ogni possibilità di esperienza emozionale, spirituale ed erotica del reale e dello spazio che ci circondano. Perché "aumentare" la realtà quando bisognerebbe semplicemente 'caricarla' per scoprirla meglio? come le "caricature compulsive" di Leonardo da Vinci, in cui da un tratto essenziale e distorto si evince mediante una descrizione e interpretazione grafica eccessiva e strabordante i tratti caratteristici di un volto, di un corpo umano, di una città, di un paesaggio. Una realtà rappresentata che non ripete sè stessa, non 'più reale più del reale', ma ancora da interpretare perché la sua vera essenza è latente, nascosta, invisibile. Esempi eccelsi sono gli studi estemporanei, caricaturali e grotteschi che travalicano la realtà nei taccuini e fogli sparsi di Victor Hugo, Delacroix, Goya, e così via . II carattere autografo e personale del disegno come espressione e penetrazione organica dello spazio sta perdendo sempre più la sua audacia e vitalità a favore di una sterile e impersonale anonimia. Appesantiti i nostri corpi sui nostri fogli di carta, appesantite le nostre mani aggrappate alle nostre matite fragili, vi è ancora una possibilità di ridare valore all'arte e alla cultura del disegno? Al disegno d'architettura come esperienza dello spazio nell'arte del vivere, nel vivere come arte, non del sopravvivere. Ripercorrere il disegno come momento originario e primordiale dell'arte, verginale, flessibile, inventivo in ogni creazione, come in pittura, in architettura, della pratica artistica in generale stabilendo un equilibrio tra esperienza tecnica della rappresentazione grafica e conoscenza, sfuggendo al controllo tecnologico, distante, ambiguo, ostinato, anestetizzante.

Fig. 4. Claudio Patanè, Diario di viaggio "Spagna" dell'autore, nelle pagine Studio dell'|glesia de San Pablo-Valladolid, Sactorellid acquerello e chir

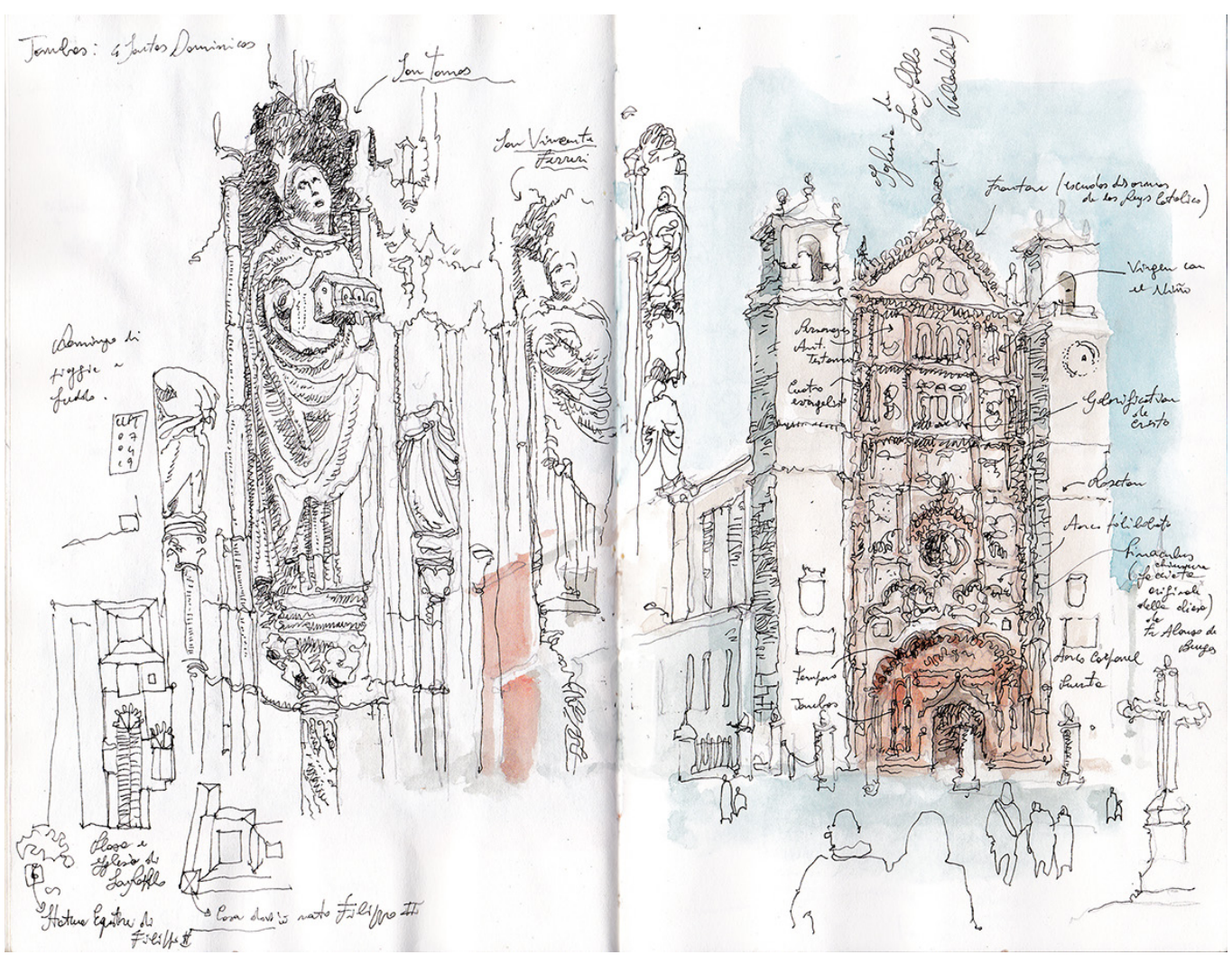


Fig. 5. Claudio Patanè, Diario di viaggio "Veneto" dell'autore, nelle pagine cattedrale del mare scoperta dell'orizzonte, acquerello e matita su carta, 2017

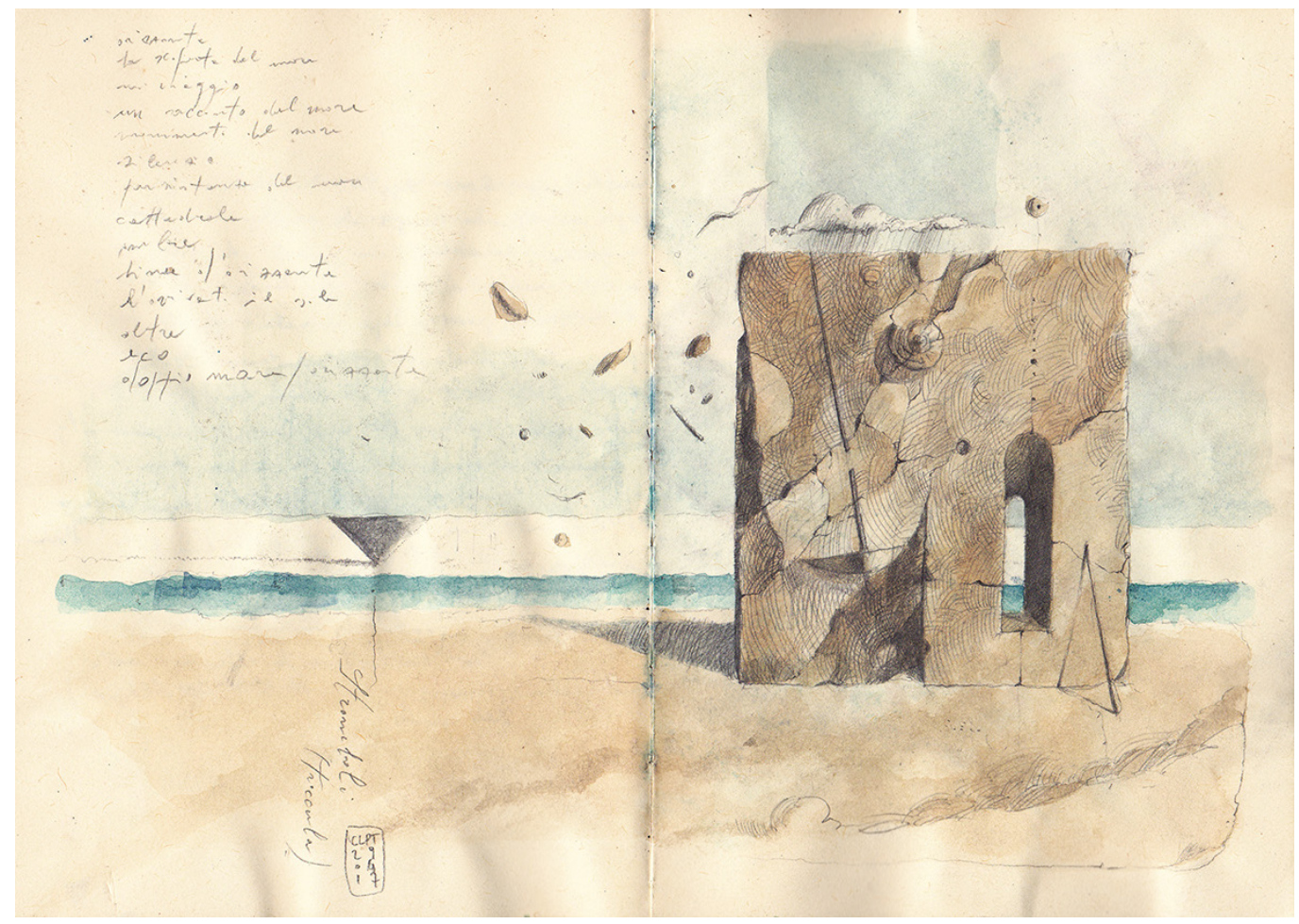

Presenza e assenza del disegno. Bisogna chiedere all'acqua

Tecniche leggere ed effimere, fragili gli strumenti da utilizzare incoerenti con la pesantezza della mano e del corpo. Sulla punta della matita resta in bilico il pingue residuo di un corpo appesantito e un'invisibilità leggera 'femminea' in cui appaiono all'origine gesti, tensioni al limite di visioni di-segni ancora a venire. Di-segni vaghi, visibili, allucinazioni, che alimentano, fluidificano e spurgano gli organici liquidi di vasi e vene cerebrali. Una realtà altra questa, parallela, spesso terrificante tendente alla distopia altre volte alla meraviglia, dettagli d'ombre di piccole finestre di un torrione sospeso tra un orizzonte fatto di cielo e di mare (fig.6). Sono elaborazioni inconsce che filtrano dalle esperienze fatte sul reale, raccolta dati, materie e composizioni, costruzioni, appunti di misurazioni "per non aver paura delle cose" [Kehlmann 20 I 4, p. 254]. Disegni come "paesaggi nella mente" [Patanè 20 I 8, p. 58-75] visioni come musiche nella memoria che si svincolano dalla apparenza della realtà. Cosa lasciare, cosa trattenere di un disegno, se non il disegno stesso, privo di parole, istante odeporico, resoconto di un viaggio a posteriori del quotidiano? "Disegnare è un'attività il cui scopo è riconoscere, e forse conciliare, l'apparente contraddizione tra presenza e assenza" [Berger 20 I7, p. I86]. Bisogna chiedere all'acqua, quando la 'mano muore' e gli strumenti diventano distanti, assenti. Sulle pagine del taccuino vuote bisogna trattenere le colature di un orizzonte equoreo (fig. 7), stendere lievi e sospesi passaggi d'acqua controllandone i gesti. Lasciar affiorare la luce dal foglio, dal contrasto di ombre proiettate da una architettura definita vaga lungo la verticalità della piega del taccuino. Lungo la piega dove si nascondono percolazioni d'acqua di disegni passati, sulle altre pagine, scarti di gomma, rimozioni di carta e graffite. Dalla piega emergerà il ciano del cielo, limpido, alternato a nuvole e macchie come d'uccelli in volo. Lasciata asciugare, evaporata l'acqua il pigmento colorato si depositerà cristallizzandosi. La matita ben appuntita e fine scoverà e traccerà spigoli, lesene, cornici e piattaforme pensili, lantane, trabiccoli, bighi roteanti, cupole, ciminiere, carrucole manomesse. L'atmosfera vaga dell'acquerello verrà corrotta dalla lucidità del tratto, così la visione si farà chiara, scolpita, architettonica (fig. 8). Un'apparizione tangibile da cui distinguere i primi piani dalla lontananza verso quell'altrove che mantiene sospeso l'occhio alato, sospeso, sognante. 
Fig. 6. Claudio Patanè,

Diario di viaggio dell autor

nella pagina Città turrita,
acquerello su carta, 2019.

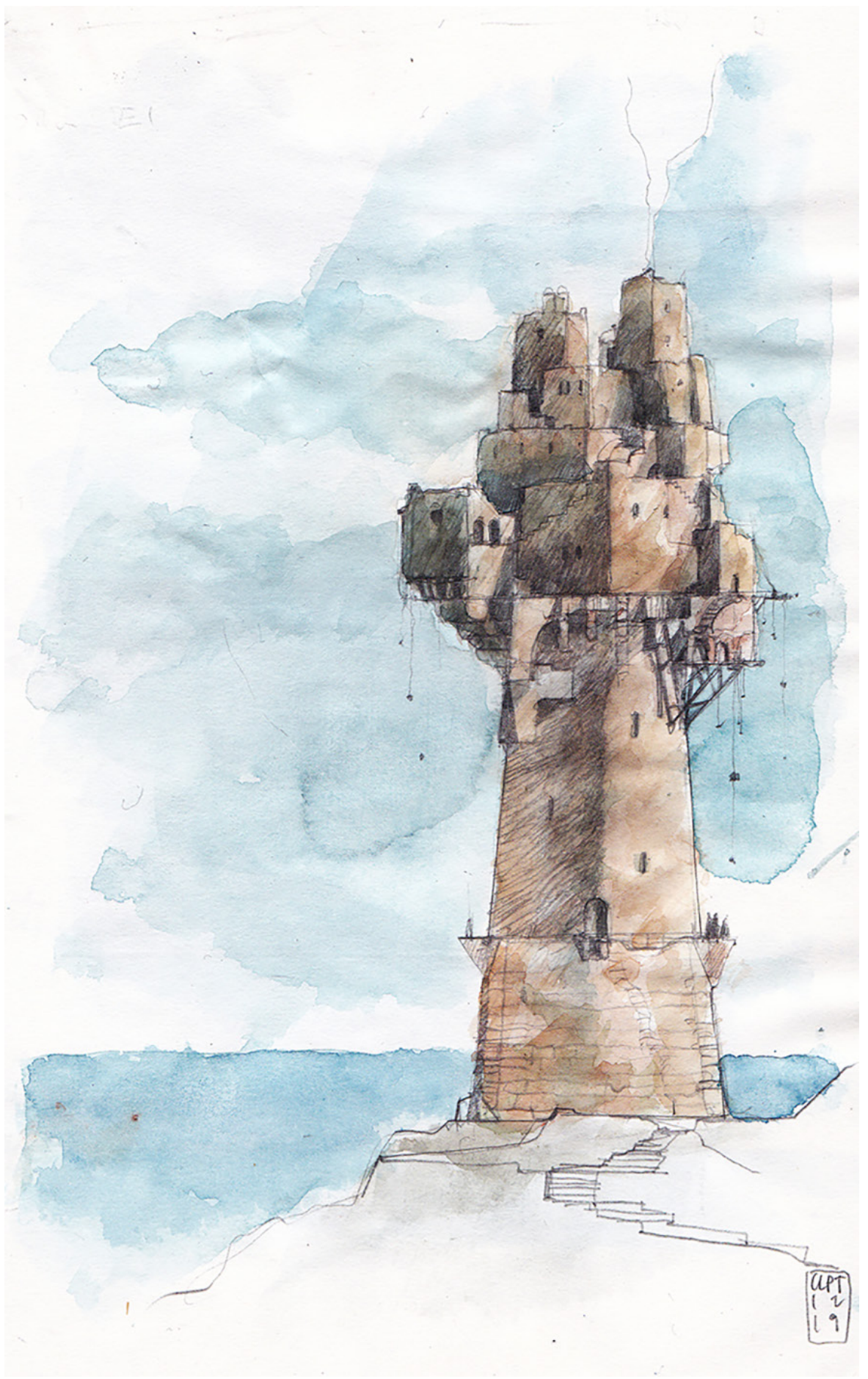




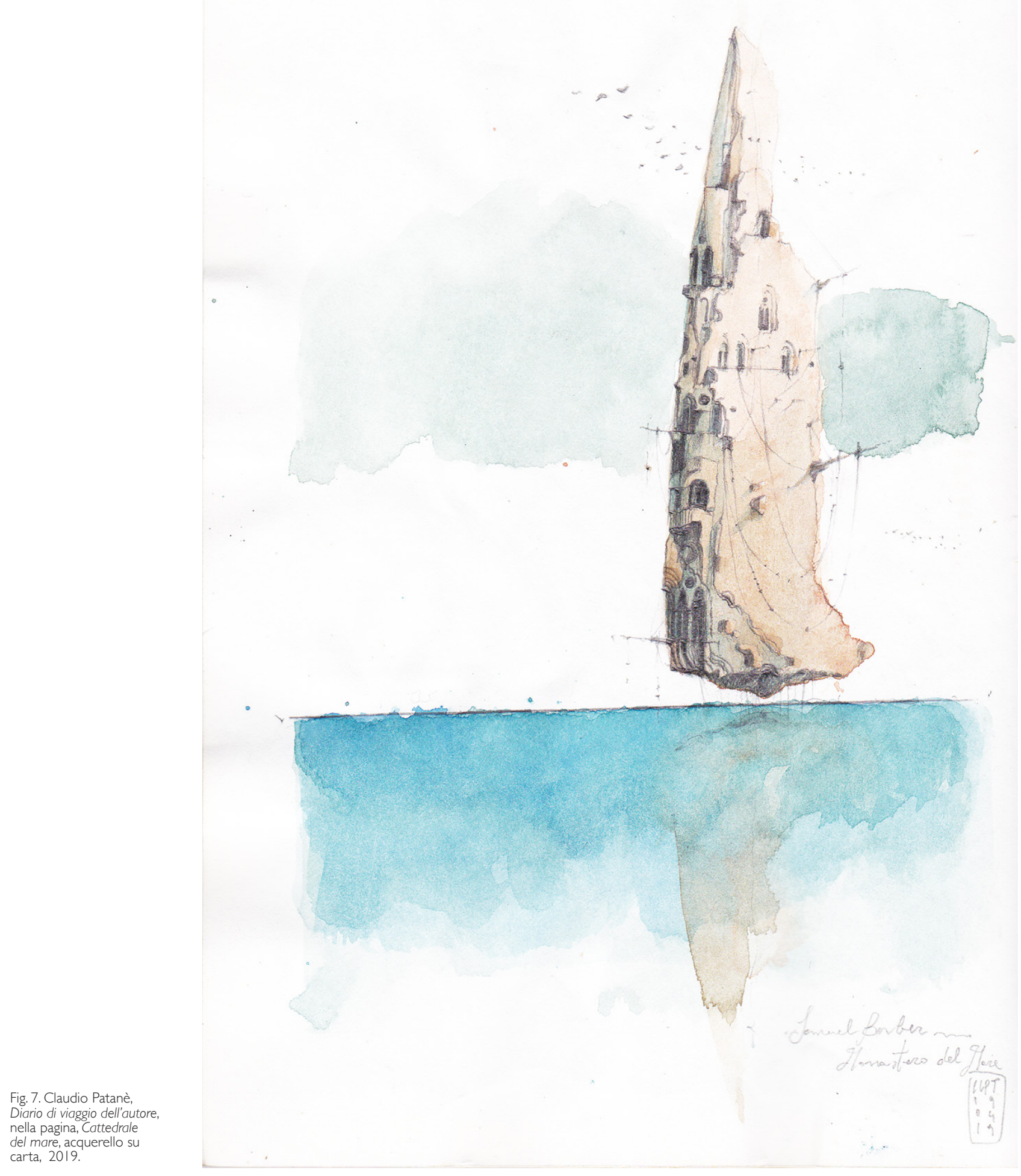




\section{Stagioni e atmosfere nel disegno}

Bisogna saper aspettare il mutare delle stagioni, per attendere il cambiare di tecniche e strumenti da utilizzare. L'atmosfera e i luoghi attraversati faranno da guida al corpo del disegnatore che cerca incessantemente risposte da ciò che vede. La carta si adatterà all'umidità e alla secchezza del clima. Gessi, carboncini, sanguigna, graffite, pastelli come polveri costruiranno le architetture e le città turrite, i ritratti e autoritratti nudi da cui scoprirsi e leggersi in una lunga notte d'inverno.

Ampi fogli si sostituiranno al piccolo diario, per una necessità di parvenze reali. Icaro è volato troppo in alto per catturare l'ombra del sole ed è precipitato, ma resta sospeso, su dei fogli bianchi per non farlo sparire e morire in mare (fig. 9). La stagione invernale fa piegare su sè stesso il disegnatore, dragando dal fondo della sua mente e dalla sua memoria, rimane al suo tavolo e ascolta: fantasie, invenzioni, visibili, visioni, mappe ricavate dalle tracce e dai brusii del proprio corpo. è incantato dalla notte, quando si concede agli inchiostri i toni utilizzati sono neri e color seppia. Le spiagge sono deserte, come il mare diventa grigio ribalta l'idea di cielo dalle tinte chiare, con nuvole basse in lontananza rarefatte di pioggia. Una città di cemento si frantuma lentamente al passaggio di una folata di vento (fig. I ), una nuvola posa ferma isolata in un cielo grigio, una donna resta ferma d'innanzi al mare sul suo balcone nell'agosto del '43, un aereo tedesco sorvola la costa orientale della Sicilia, un bastone da passeggio giace tra gli scogli abbandonato. Qualcuno ha preso il largo senza più tornare a riva.

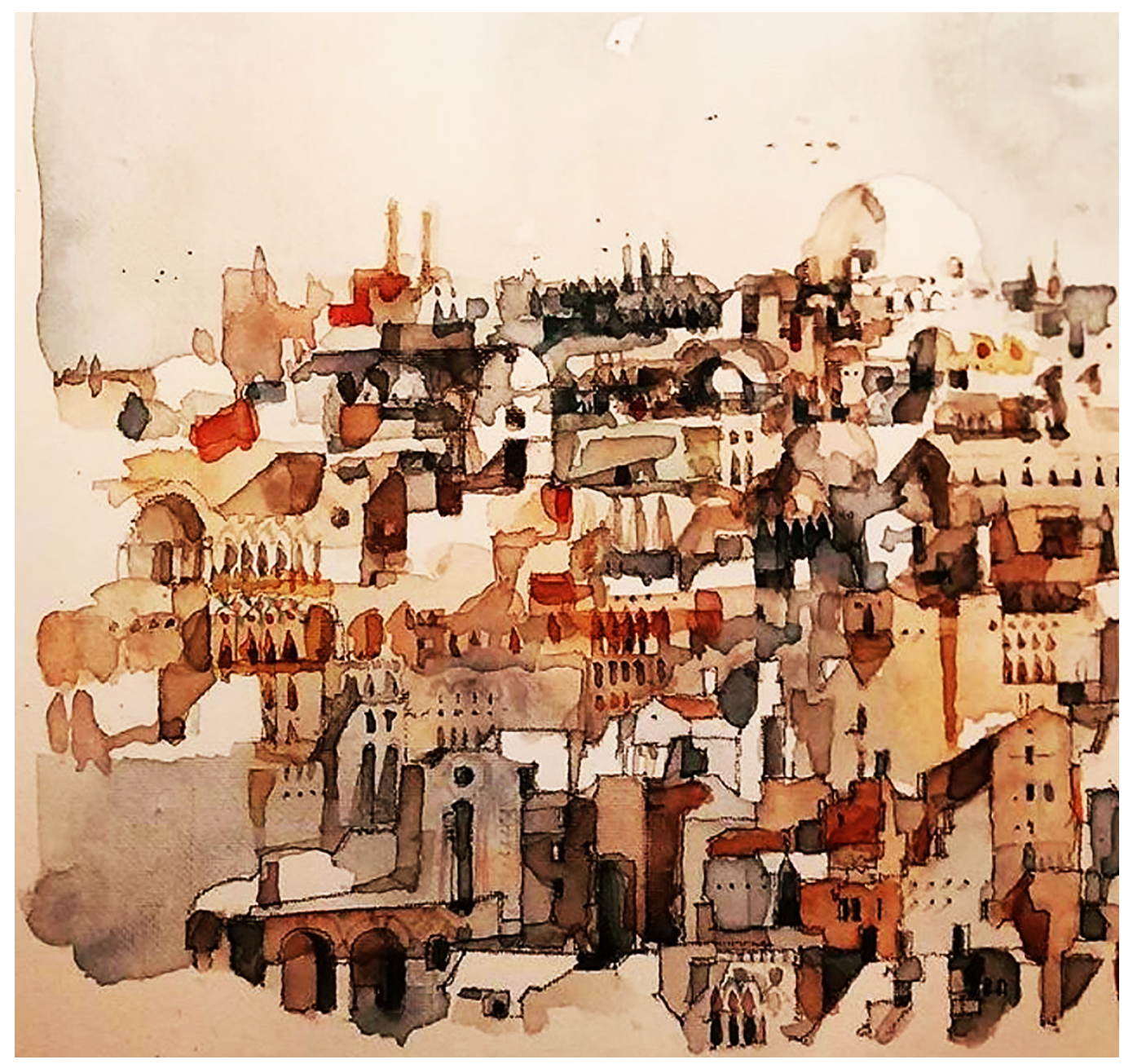


II tempo del colore è quello del visibilio, dell'occhio "luminoso, chiaro e puro"." Se l'occhio non fosse solare, mai potrebbe guardare il sole. L'occhio deve la propria esistenza alla luce; così l'occhio si è formato dalla luce per la luce, affinché la luce interiore potesse incontrarsi con quella esteriore" [Di Napoli 2004, p. 5 I 3]. La luce è quella del mediterraneo, della sua atmosfera primaverile ed estiva, in contrasto è il 'lutto' [Bufalino 1997]. Uno scorcio tra case abbandonate dai coloro intensi, di pietra lavica antica, fa intravedere lo lonio e giù in fondo il salto lieve Ibleo e Siracusa. (fig. I2)

Ci si abbandona all'atmosfera dello stretto tra la Sicilia e la Calabria, cerca di ritrovare il tempo rimasto per il disegno d'acqua, fatto di afa e canicola estiva, il tempo dello stato fluido, equoreo, miscela di scirocco e sale che resta attaccato alle lenti degli occhiali e alle mani. Circolano le navi e bastimenti, (fig. I I) seguendo la linea d'orizzonte mobile attraverso i finestrini dell'aliscafo. Due lembi di terra antica si raffrontano, difficile definire quale sia l'isola. Altalenante è l'imbarcazione, la mano e il pennello seguono il suo ondeggiare, l'orizzonte tra mare e cielo si accumulano sulla carta trattenendone i riverberi di ultime luci a ponente e i refoli dello scirocco in ascesa.

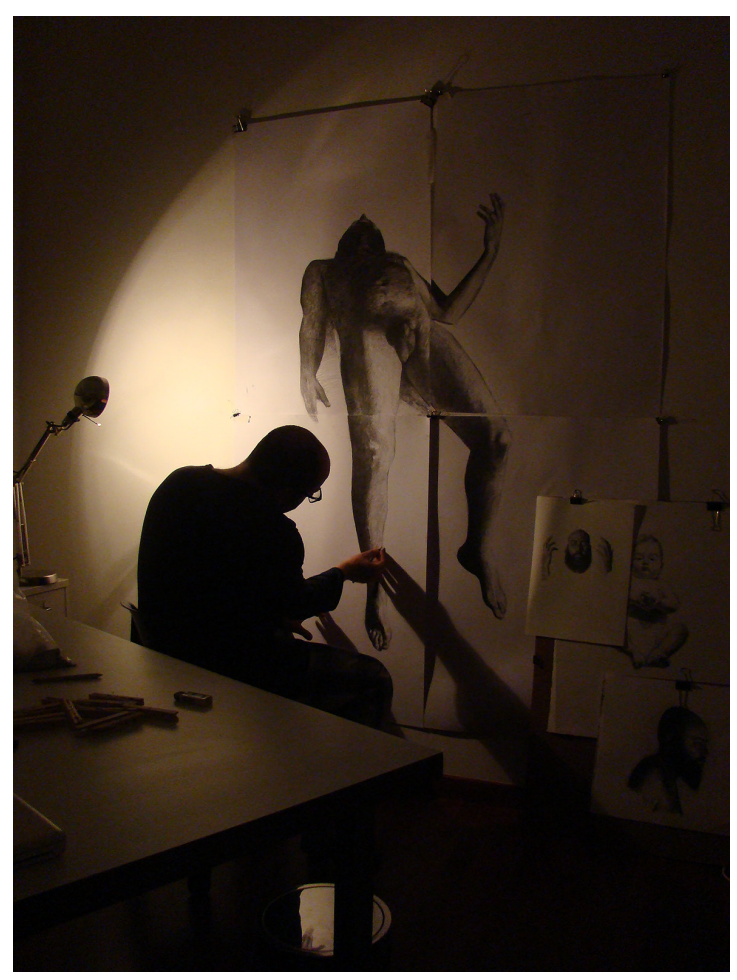

\section{Verifica incerta. Quel che resta del mondo in una dimensione piccola, un diario}

II disegno su taccuino non ammette conclusione, tende all'incompiuto, a lasciar in sospeso il 'regesto' di ciò che è guardato e conosciuto del mondo che ci circonda. Minuta la sua dimensione, il diario, costringe a disegnare in forma piccola, fragile ed essenziale, compulsiva, incerta. E per questo tende a disperdersi e a non riconoscersi come opera. Se non come opera palinsesto nata postuma in cui la vita si sostituisce al divenire di una ricerca estetica ed artistica. Come nella prime piccole sculture 'arcaiche' di Alberto Giacometti, in cui l'artista sottraeva peso alla materia, per una tensione gestuale delle sue mani alla prensione aptica, riduceva ai 'minimi termini' la dimensione e la plasticità della sua primordiale opera. Quasi un atto di protezione a contenimento nelle sue mani fino al raggiungimento di una dimensione piccola, spuria, corrosa dallo spazio che la conteneva. Dimensioni disperse, caduche, senza traccia lasciata. Lo stesso in un diario grafico: abbozzi, appunti di un discorso infinito, sporco, con sè stesso da scartare per ricominciare nuovamente. Una costrizione retta da tentativi 
Fig. 10. Claudio Patanè, Diario di viaggio dell'autore, nella pagina Casa in riva al mare, inchiostro su carta, 2019 .

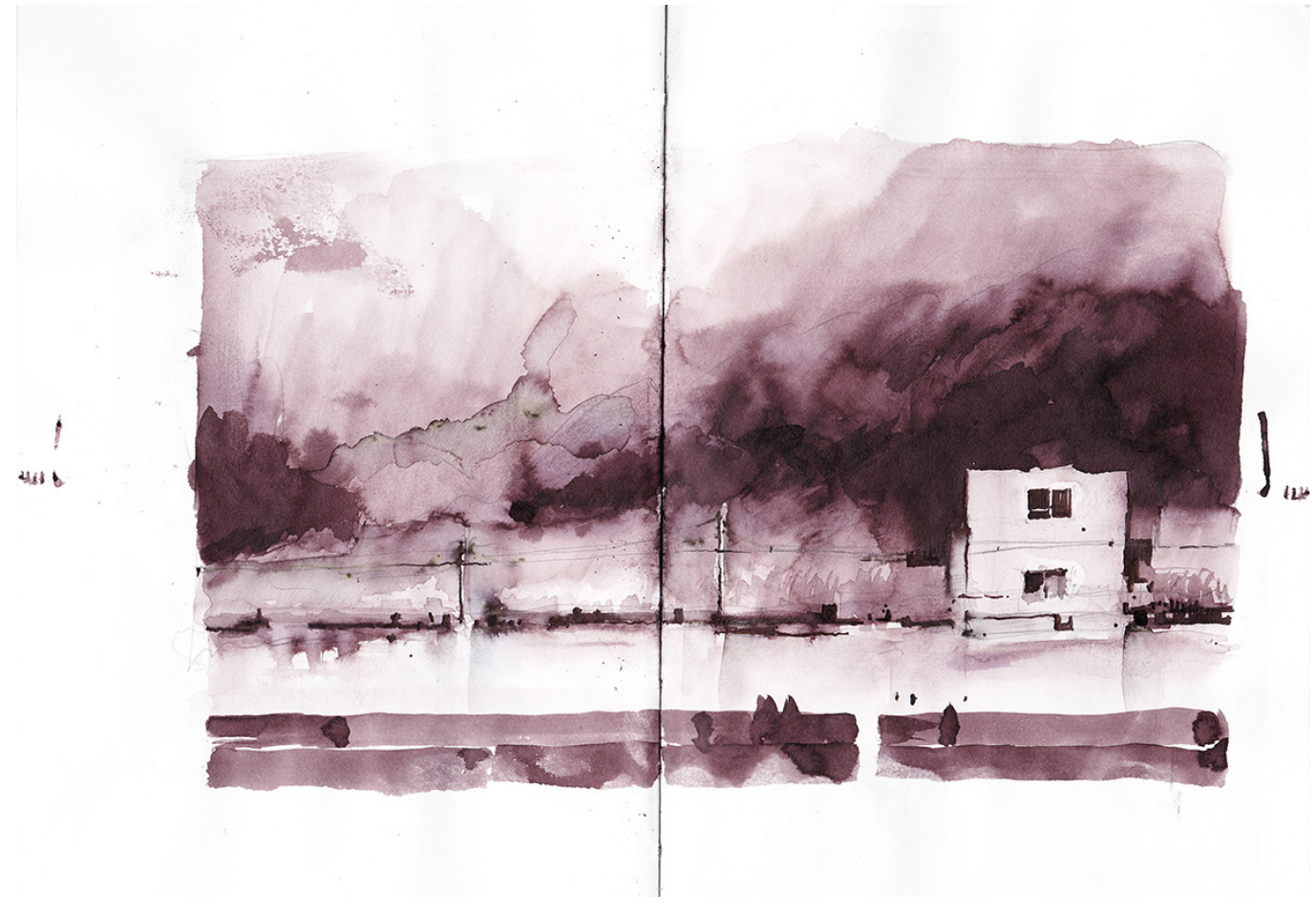

impulsivi primordiali e arcaici. Questa disseminazione intima, occulta, in cui l'autore parla con se stesso, nasconde e custodisce, si riscontra come un irradiarsi sensoriale ed emozionale nell'immenso Codice Atlantico di Leonardo, nei Carnet de voyage di Le Corbusier (sono trattati di architettura), nei minuziosi 48 acquerelli (formato $4 \times 6 \mathrm{~cm}$ ) "osservazioni elementari sulla natura e l'artificio ad uso improprio" di Massimo Scolari, in musica negli enigmatici ultimi 'piccoli' quartetti per archi di Beethoven e Borodin. Nascono postume al suo nascere, queste opere proprio perché segrete, timidamente, ascoltate, spesso guardate solo da pochi amici intimi. Francesco Moschini nell'introduzione all'opera "Acquerelli e Disegni 1965-1980" di Massimo Scolari così concluderà il suo preambolo: "Ed allora si fa più pressante la necessità che, al di là degli elementi più tipicamente pittorici, un disegno insistito e minuzioso accompagni quasi come un controcanto le singole opere di Scolari, sino a farsi verifica del già trattato e proposta di novità su scarti appena percepibili rispetto alle acquisizioni raggiunte. II disegno diventa così autonoma formulazione con una propria vita. Ed i suoi ritorni, le sue ossessioni, sembrano registrati su quei taccuini-breviari cui Scolari pare legare le più spaziate riflessioni e le più minute annotazioni solo apparentemente sempre simili a sè stesse" [Moschini 1980, p. 14].

\section{Riferimenti bibliografici}

Agostino, Sant' (2000). Le Confessioni. Torino: Einaudi Gallimard. Traduzione di Carlo Carena.

Berger John (20/4). Il taccuino di Bento.Vicenza: Neri Pozza Editore. Traduzione di Maria Nadotti.

Berger John (20 17). Sul disegnare. Milano: II Saggiatore. Traduzione di Maria Nadotti.

Berger John (2017). Confabulazioni.Vicenza: Neri Pozza Editore.Traduzione di Maria Nadotti.

Bufalino Gesualdo (1997). La luce e il lutto. Roma: Editori Riuniti.

Debord Guy (1956). Théorie de la dérive. Bruxelles: n. 9. (Ripubblicato senza le due appendici in Intenationale Situationniste, n. 2, dicembre 1958, Parigi. Trad.it. Internazionale Situazionista, Nautilus, Torino).

Di Napoli Giuseppe (2004). Disegnare e conoscere. La mano, l'occhio, il segno. Torino: Piccola Biblioteca Einaudi.

Edwards Betty (2002). II nuovo Disegnare con la parte destra del cervello. Milano: Longanesi Edizioni. 

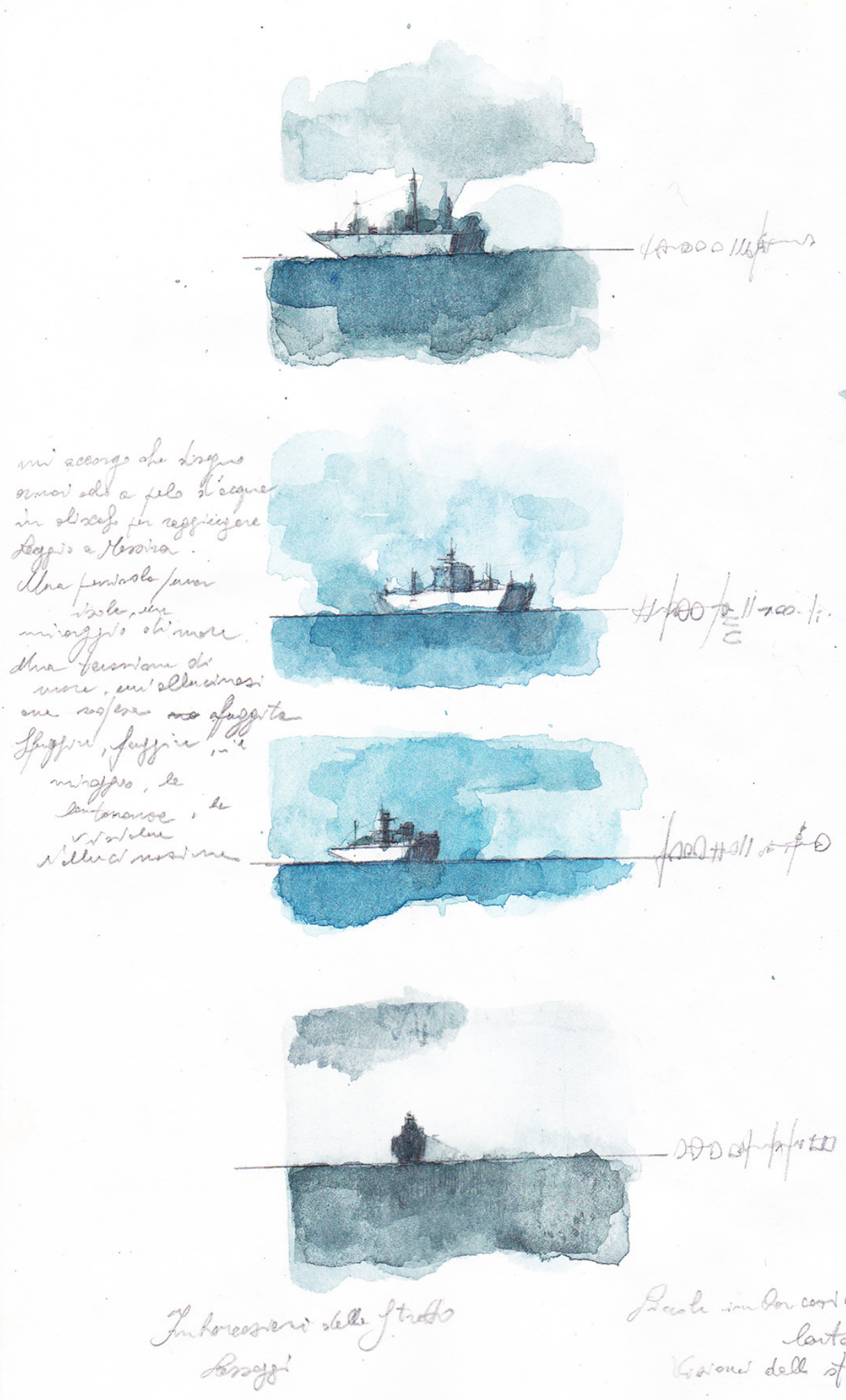

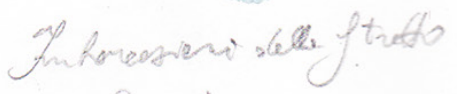

$$
\begin{aligned}
& \text { soroge? }
\end{aligned}
$$

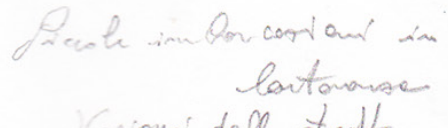


Fig. 12. Claudio Patanè, Diario di viaggio dell'autore, nella pagina Lo lonio attraverso, acquerello su carta, 2019

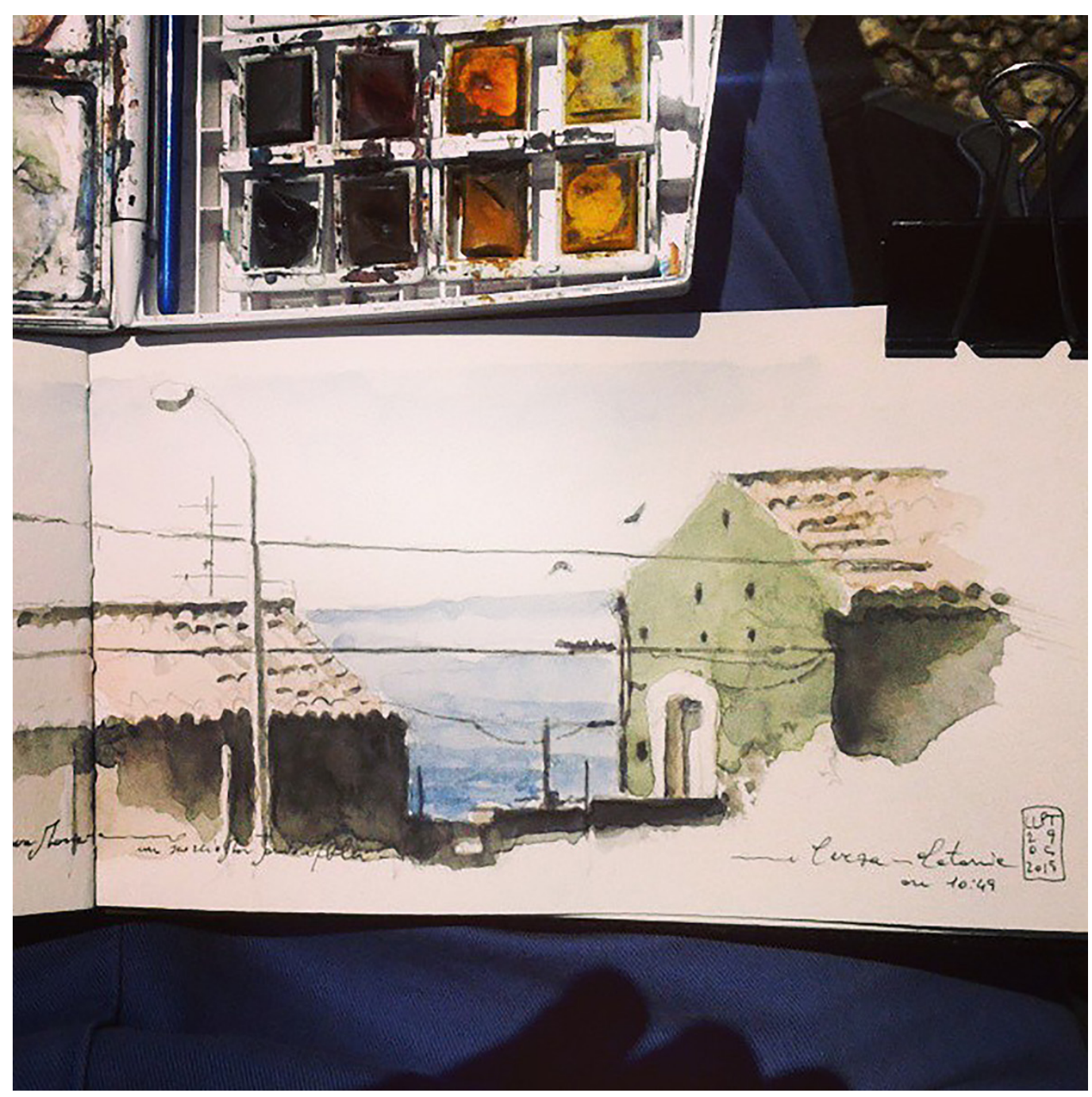

Foti Fabrizio (2016). La via del disegno. Siracusa: Lettera Ventidue Edizioni.

Kafka Franz (2004). Aforismi di Zürau. Milano: Piccola Biblioteca Adelphi.

Kehlmann Daniel (20|4). La misura del mondo. Milano: Feltrinelli. Traduzione di Paola Olivieri.

Moschini Francesco (1980). Massimo Scolari. Aquerelli e disegni 1965-1980. Firenze: ed. Centro Di.

Patanè Claudio (20 I8). Orizzonti nella mente. In Suq. Unconventional Sicily \#0, pp. 58-75.

Perec George (1994). L'infra-ordinario. Torino: Bollati Boringheri. (Traduzione di Roberta Delbono).

Rosa Ugo (2002). Dei disegni ultimi (su Mario Ridolfi). In Arch'it (FILES), I 3 febbraio 2002, p. I.

Autore

Claudio Patanè, Università Mediterranea Reggio Calabria, claudio.patane@unirc.it

Per citare questo capitolo: Patanè Claudio (2020). 'Custodiari' del tempo. II corpo, il viaggio, il disegno/'Custodiari' in the time. The body, the travel, the drawing. In Arena A., Arena M., Brandolino R.G., Colistra D., Ginex G., Mediati D., Nucifora S., Raffa P. (a cura di). Connettere. Un disegno per annodare e tessere. Atti del $42^{\circ}$ Convegno Internazionale dei Docenti delle Discipline della Rappresentazione/Connecting. Drawing for weaving relationships. Proceedings of the 42th International Conference of Representation Disciplines Teachers. Milano: FrancoAngeli, pp. 3634-3659. 


\title{
'Custodiari' in the Time. The Body, the Travel, the Drawing
}

\author{
Claudio Patanè
}

\section{Abstract}

The perception of travel today has been reduced simply to a departure and a final destination. The logic of 'package tour control, all inclusive!' has prevailed to the detriment of the true essence of the journey in everyday life, its 'during'. The photographic instantaneousness and the compulsive divulgation on the web and in the social networks of the places visited, has made the traveller distracted, stopping that desire for discovery, slowness, memory and narration in which one gets involved during the trip and returning home. To consume with the look and give back through drawing, on a diary, a face, a place or a city that we do not know, means to become 'pause' in an itinerary, to be a receptive narrating body of what we cross. Advancing, on foot, with a notebook in hand, changes the perception of space, before the 'di/segno' reveals a glimpse and, further on, the wide widening towards a landscape. The proposed communication intends to present some reflections starting from personal experiences narrated and represented in my 'travel diaries', in the everyday life and outside it. These experiences have highlighted the need to proportion and contain the embrace of a glance of a place, inside a small 'travel case', a diary, made of pages, ink and so on. Support of recording, knowledge, accumulation of memories, sensory device and extension of my wandering body.

Keywords

diary, drawing, analog, travel, Mediterranean.

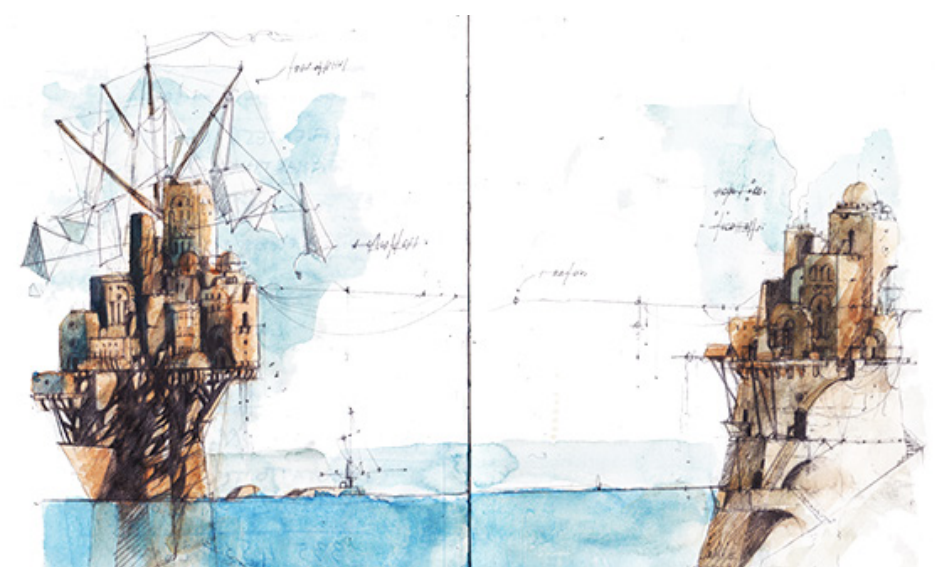




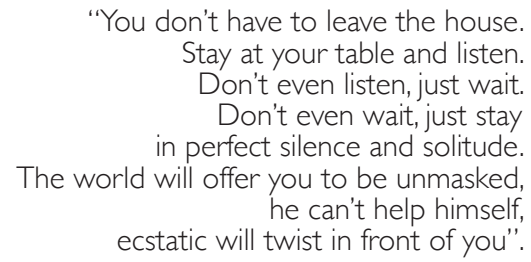

[Kafka 2004]

A last great drawing represents an architecture made of kites flying on a sunny beach. An asymmetrical kite, made of many pieces of colored paper (in turn small kites), held together by wooden rods, cables, wires, knots. It almost struggles to soar in flight, getting up heavy, skimming the earth, level with the ground. Someone said that it will be enough to balance the weight, distribute the loads and rearrange the axle through hanging counterweights, harnesses and keels to make it fly. Drag behind it, knotted a small house, (stone cabin?). He eradicates it from its foundations, from its fixity, immobility, from its matter. In the background a horizon made of sea, equoreo and in the distance a sailboat, or a sailing ship who knows, you do not recognize the size so far away.A paradox is this drawing (fig. I), an enigma, a rebus from which to reveal the code if you succeed, it is a secret. This scene has a title: Aquilone $n 2$, and at the bottom an anagram and the date, 2019. John Berger writes: "We who draw do so not only to make something visible to others, but to accompany something invisible to its incalculable destination" [Berger 2014, p. 176]. And the great drawing Aquilone $n 2$ accompanies "something invisible to its incalculable destination". Just as John Berger accompanies his friend Marie-Claude, to her "incalculable destination" her death, by placing inside her coffin a drawing of coloured pastel irises and saliva (this is how the philosopher, storyteller, compulsive draftsman), caught in graphic form, for her the day before, from her terrace. Berger delivers to the incalculable and invisible destination the portrait of the most loved and beautiful flower by her dear friend in life, offering with generosity and tenderness "in the dark what does not die but hides elsewhere, in another place" [Berger 20 I7, p. I 32]. The coffin becomes eternal custody, "of guests in the dark" [Berger 2017, p. I32] to keep in the shadows that elsewhere of what has disappeared and will disappear but "in which the

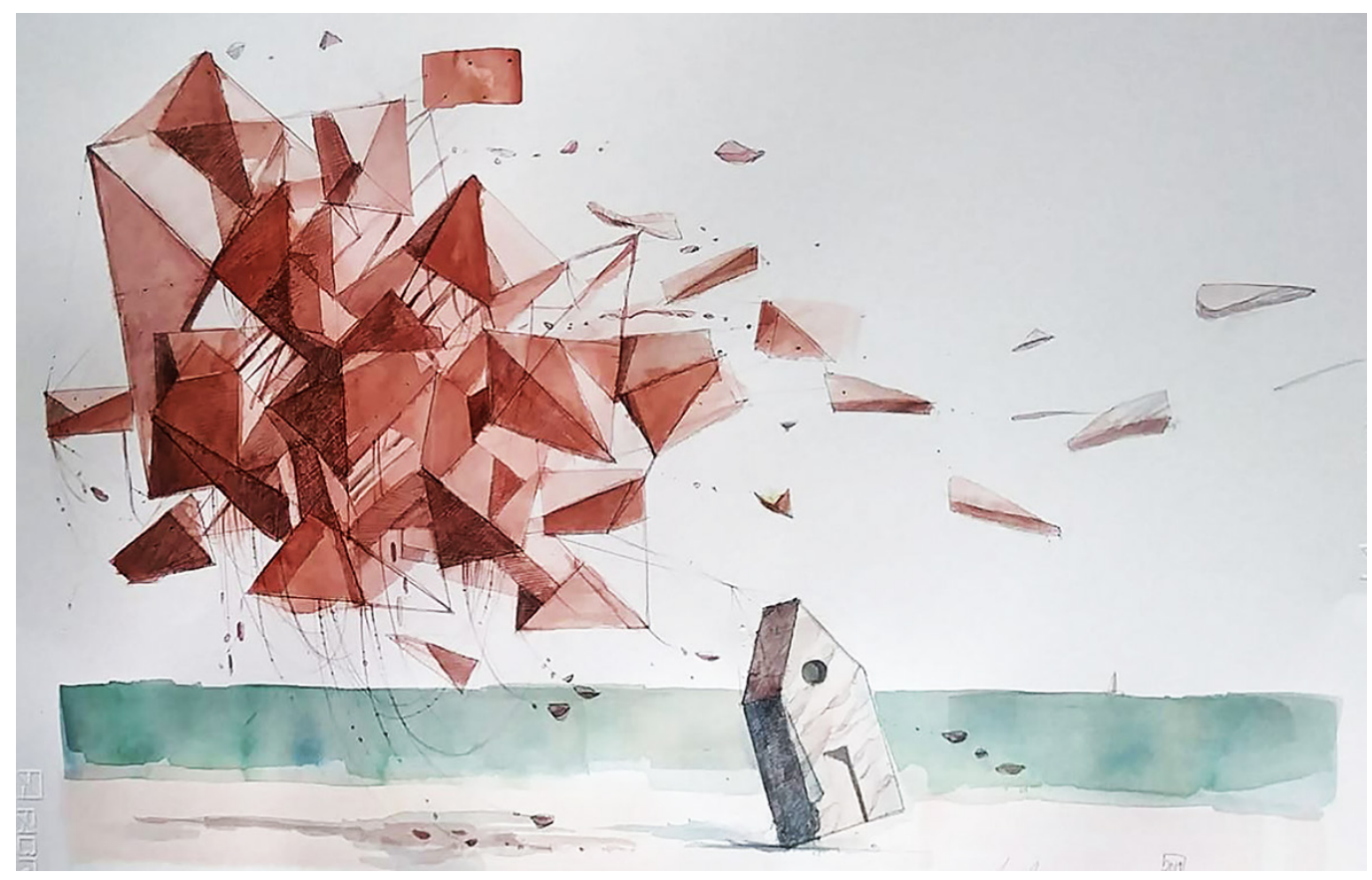


future that is ours and theirs together [...] resets the linear calculation of time" by denying "its bureaucratic peremptoriness" [Berger 20 I7, pp. I31, I32].

In this will to hide, to keep the secret in time, to conceal, lies the reflection that I am going to document, using as a material of examination the 'custodiari' drawn and built during the last years. An account of a journey, in which the everyday and not only, through the work of graphic narration, expands in time, becomes immense, in which, as Saint Augustine will write: "the present of the present becomes a vision" [Agostino 2000, p. LIX-826].

The travel diary becomes a 'travel custodiario' (fig. 2), when the object itself becomes a paper support not only to represent reality, but a custodian to keep that "infra-ordinary" [Perec 1994] that escapes everyday life.

The object becomes "manuscript", susceptible to temporal, spatial, dimensional variations. Memory becomes living matter, which fills the shelves with its body, produces dust, swelling, excrescence, sensitivity to deterioration. The "custodia" protects and preserves the remains of that "secret laboratory" [Foti 20 I 6] (fig. 3) in which artistic practice, as experience, becomes a tangible practice of revealing the everyday, the reality that surrounds us and knowledge. The diary is a small, discreet entity that hides the representation of the world to preserve it as something precious, secret, mound and tomb, "to accompany something invisible to its incalculable destination". It does not expose itself because it is an unfinished container, guardian of abortions, attempts, expectations.
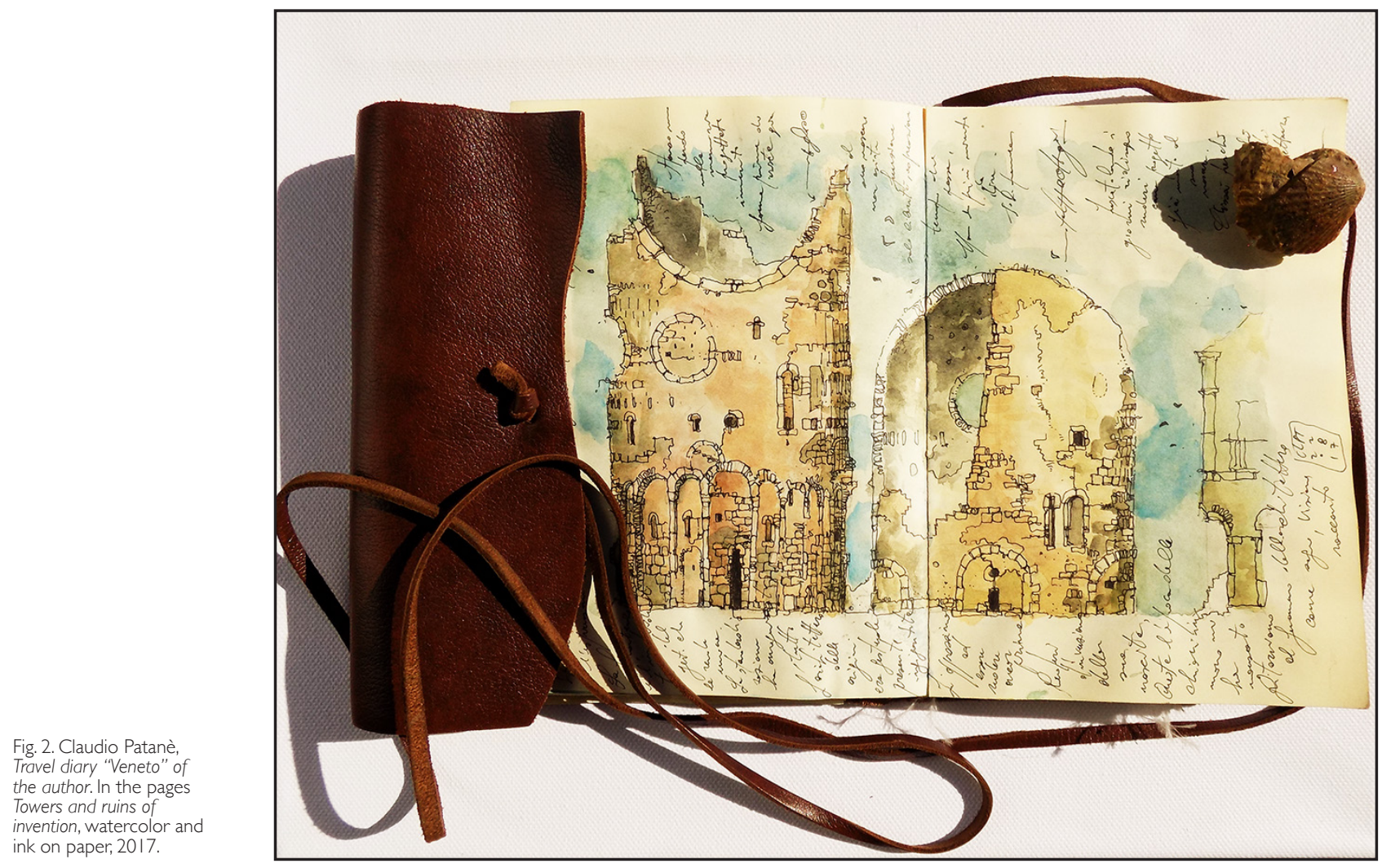

Body weight. The weight of the paper. The weight of the drawing

You start by walking, experiencing walking as a conscious practice of crossing, recognizing yourself as an active, living, sensitive part of a path. Leaving a trace of one's own itinerary through the footprints re-calced on earth. A path that also invites you to drift [Debord 1956] losing yourself, staying in time, at the pace of the world. Afterwards, the step alone is no longer enough, one feels the need to make the path a story, making the things seen 
tangible, marking time by pauses, in which a place is chosen to sit, stop, "consume" with the look and represent it in a notebook. A compulsive bulimia in holding objects, natural things, real fragments of places, landscapes, cities crossed, the whole world internalized, filtered by the body, by the eyes of the mind. It is the free, freehand drawing, the most ancient spiritual form of narration, anarchic, unfinished, infinite, alive (fig. 4). The choice of a geographical place where to position oneself reacting to the atmosphere, radiating to space, detecting its essences, presences, other temporalities. "Pausing" becoming the stopping same path, active, disturbing. "I, who proceeded blindly, led myself to see. I saw. And I was amazed and enchanted by what I saw, and I wished to identify with it" [Edwards 2002, p. 276] . The act of drawing from life allows us to identify ourselves with the subject/object/landscape portrayed, becoming a living part of it, merging with it, assimilating dimensions, immersing ourselves in materials, colours, textures, movements, shadows, passages of time. The initial excessive writing gives way to the graphic note, illustrated, to the superimposition of signs, which knows no direction, direction, structure as in writing. The free drawing, follows the

Fig. 3. Claudio Patanè, Travel diary "Veneto" of the author. In the pages Samples of the sea, watercolor pencil and ink on paper 2017

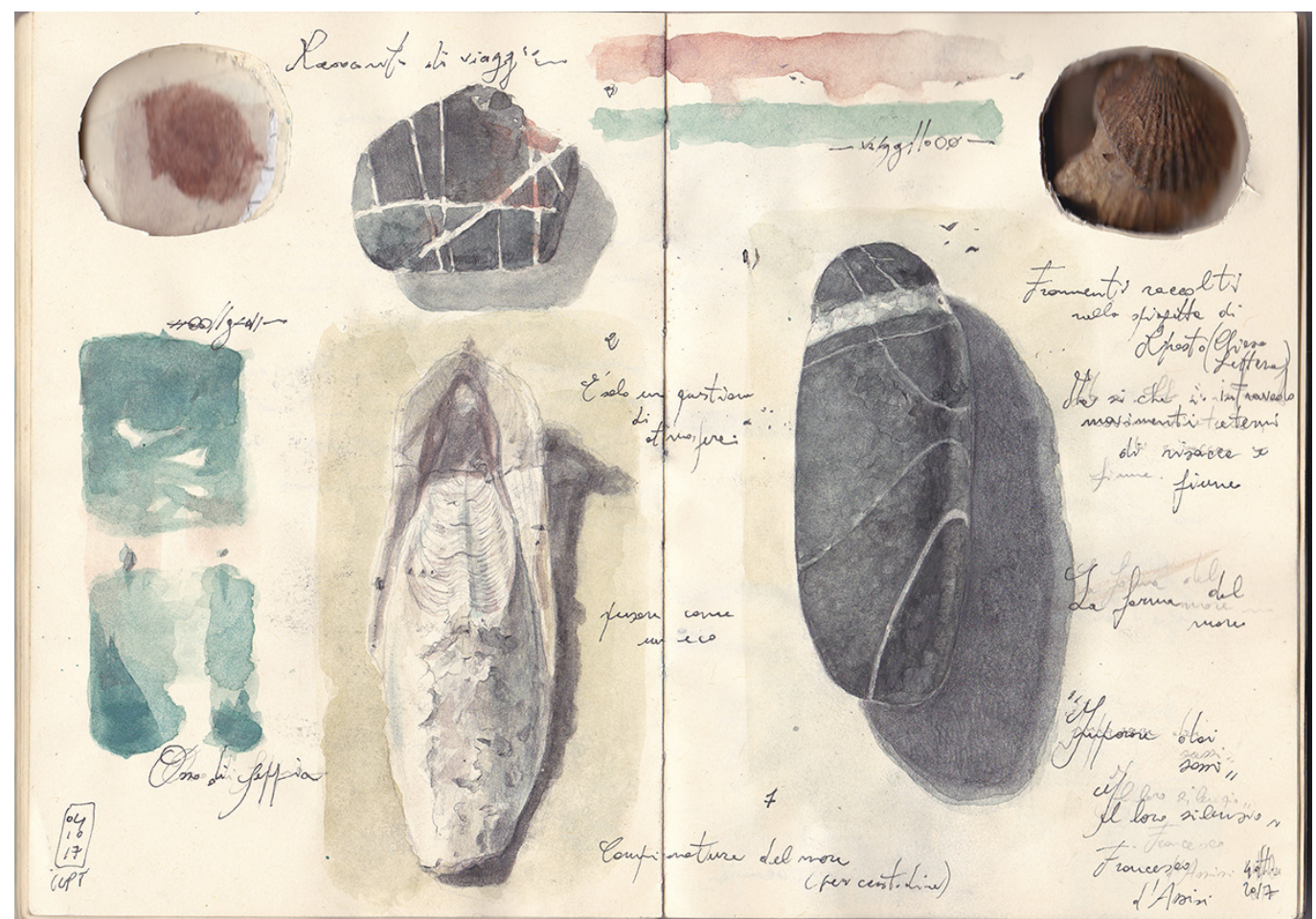

rules of the proximity system and relationship between lines, points and surfaces, captures the enigma of depth, identifying in the processuality of the gesture and in the pressure of the hand an overlapping of inaccuracies that blunt, distilled, corrected, proportionate establish a harmony between signs, drippings and the rest of the white, rippled surface of the sheet of paper (fig. 5). Drawing with only colored lines and water, poor, fragile, does not become an icon or simulacrum, it does not immortalize as in photography, but generates life [Berger 2017, p. 186] because its tension allows to identify with the temporality and process that makes it, escaping the laws of appearance. The drawing of the world "weighs" on the sheet of paper but is weightless. As in the design of architecture or a city, the law of gravity and its real and static construction are renounced. Ugo Rosa will write in this sense in the drawing of architecture in Mario Ridolfi's work: "the drawing is, in short, the architects' menstrual period: of course in these cases, unfortunately increasingly rare, in which it is not gonorrhea. Through the drawing, architecture absolves itself from the construction and gravity of the 
law, renounces birth and is expelled, already somehow "finished" but still obscurely palpitating, saturated with promise. There is no architect, any more than Mario Ridolfi, in whom the drawing shows more clearly this menstrual characteristic, of obscure and bloody purging, of slag that already death overshadows and that, too, remains unmistakably pulsating, mysteriously vital" [Rosa 2002, p. I]. These words sound uncomfortable at a time when the loss of lucidity towards the experience of the drawing of the real in favor of the experience of virtual, mass media and absence has made and benefited those lobbies and servants of capitalist technology, making standardizing, empty, equal to itself, tired and bored every possibility of emotional, spiritual and erotic experience of the real and the space around us. Why 'aumentare' reality when we should simply 'caricarla' it up to discover it better? like Leonardo da Vinci's 'compulsive caricatures', in which an essential and distorted trait can be seen through an excessive and overwhelming graphic description and interpretation of the characteristic features of a face, a human body, a city, a landscape. A represented reality that does not repeat itself, not 'more real than real', but still to be interpreted because its true essence is latent, hidden, invisible. (Excellent examples are the extemporaneous, caricatured and grotesque studies that go beyond reality in the scattered notebooks and sheets of Victor Hugo, Delacroix, Goya etc). The autograph and personal character of drawing as an expression and organic penetration of space is increasingly losing its audacity and vitality in favour of sterile and impersonal anonymity. Weighing our bodies on our sheets of paper, weighing down our hands clinging to our fragile pencils, is there still a chance to restore value to art and drawing culture? To architectural drawing as an experience of space in the art of living, in living as art, not of surviving. Retracing drawing as the original and primordial moment of art, virginal, flexible, inventive in every creation, as in painting, in architecture, in artistic practice in general, establishing a balance between technical experience of graphic representation and knowledge, escaping technological control, distant, ambiguous, obstinate, anesthetizing.

Fig. 4. Claudio Patanè Travel diary "Spain" of the author. In the pages Study afther. In the pages Stud - the Iglesia de San Pablo and ink on paper, 2019

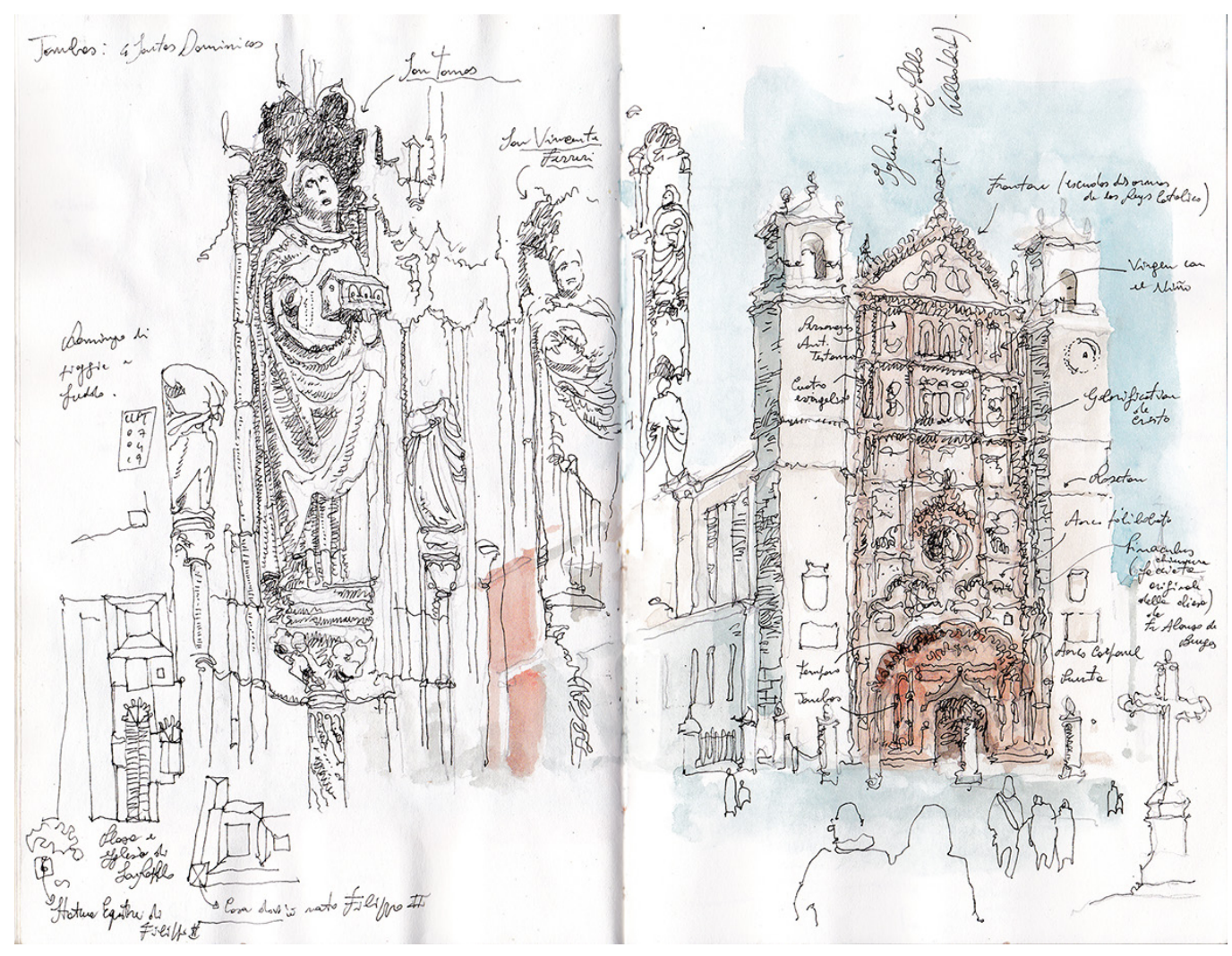


Fig. 5. Claudio Patanè, Travel diary "Veneto" by the author. In the pages Cathedral of the sea-the discovery of the horizon, watercolor and pencil on paper, 2017.

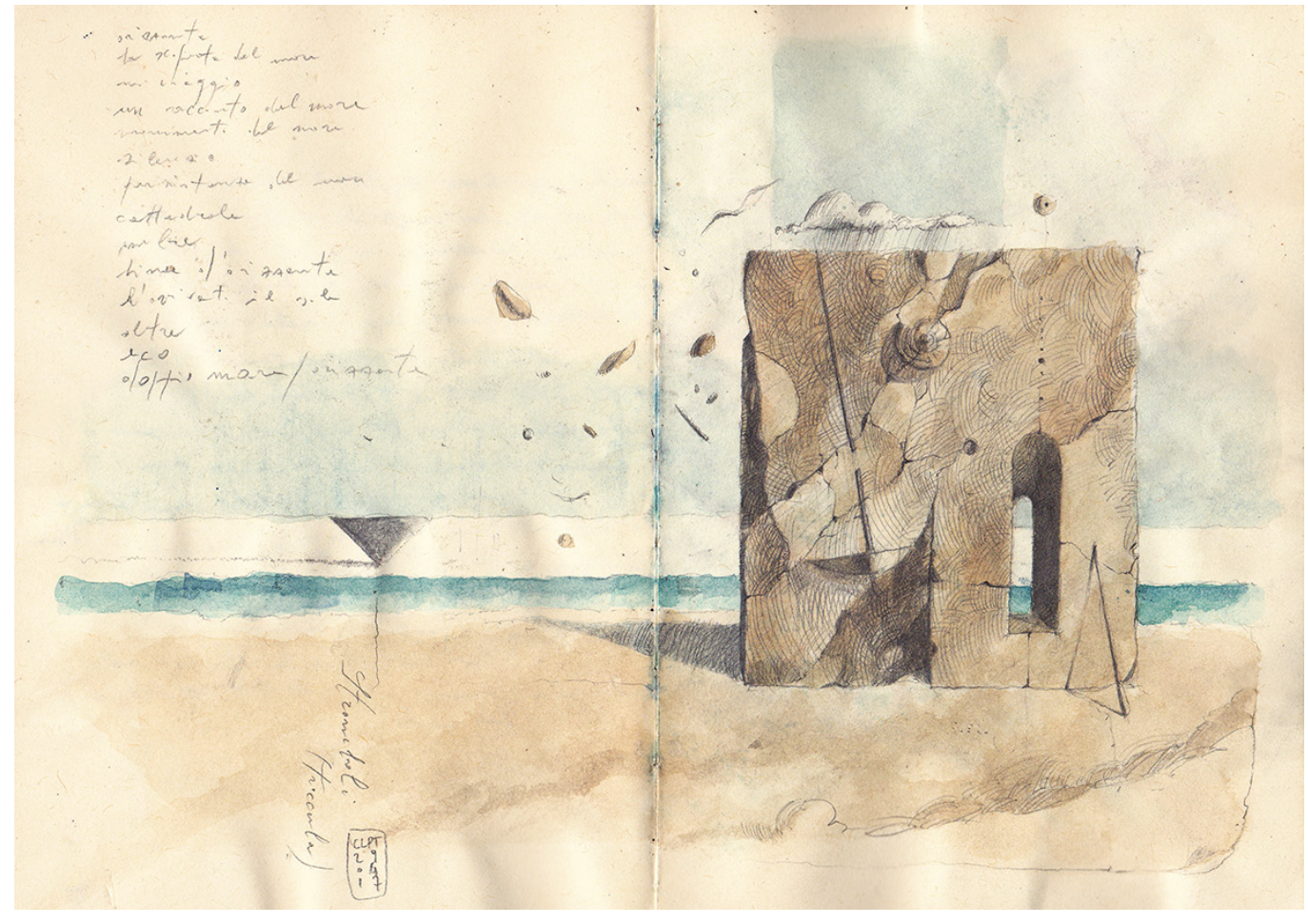

Presence and absence of the drawing. Ask the water

Light and ephemeral techniques, fragile instruments to use inconsistent with the heaviness of the hand and body. On the tip of the pencil remains in the balance the residual tongues of a heavy body and a light 'feminine' invisibility in which appear at the origin gestures, tensions at the limit of visions of signs still to come. Vague, visible, hallucinating signs that feed, fluidify and purge the liquid organs of cerebral vessels and veins. Another parallel reality, often terrifying, often tending to dystopia, other times to wonder, details of shadows of small windows of a tower suspended between a horizon made of sky and sea (fig. 6). They are unconscious elaborations that filter from experiences made on reality, data collection, materials and compositions, constructions, notes of measurements "not to be afraid of things" [Kehlmann 20 I 4, p. 254]. Drawings like "landscapes in the mind" [Patanè 20 |8, p. 58-75] visions like music in memory that are free from the appearance of reality. What to leave, what to keep of a drawing, if not the drawing itself, devoid of words, an odeporic moment, an account of an a posteriori journey of everyday life? "Drawing is an activity whose purpose is to recognize, and perhaps reconcile, the apparent contradiction between presence and absence" [Berger 2017, p. 186].

You have to ask the water, when the 'hand dies' and the instruments become distant, absent. On the empty pages of the notebook you have to keep the drippings of an equorae horizon (fig. 7), spread light and suspended passages of water controlling its gestures. Let the light emerge from the sheet, from the contrast of shadows projected by a defined architecture vague along the verticality of the fold of the notebook. Along the fold where there are hidden water marks of past drawings, on the other pages, rubber scraps, removal of paper and graphite. From the fold will emerge the cyan of the sky, clear, alternating with clouds and spots like birds in flight. Once the water has evaporated, the coloured pigment will settle and crystallize. The pencil well pointed and fine will find and trace edges, pilaster strips, frames and hanging platforms, lanterns, trabiccoli, rotating bighi, domes, chimneys, pulleys tampered.The vague atmosphere of the watercolour will be corrupted by the lucidity of the stroke, so the vision will become clear, sculpted, architectural (fig. 8). A tangible apparition from which to distinguish the close-ups from the distance to that elsewhere that keeps the winged, suspended, dreamy eye suspended. 


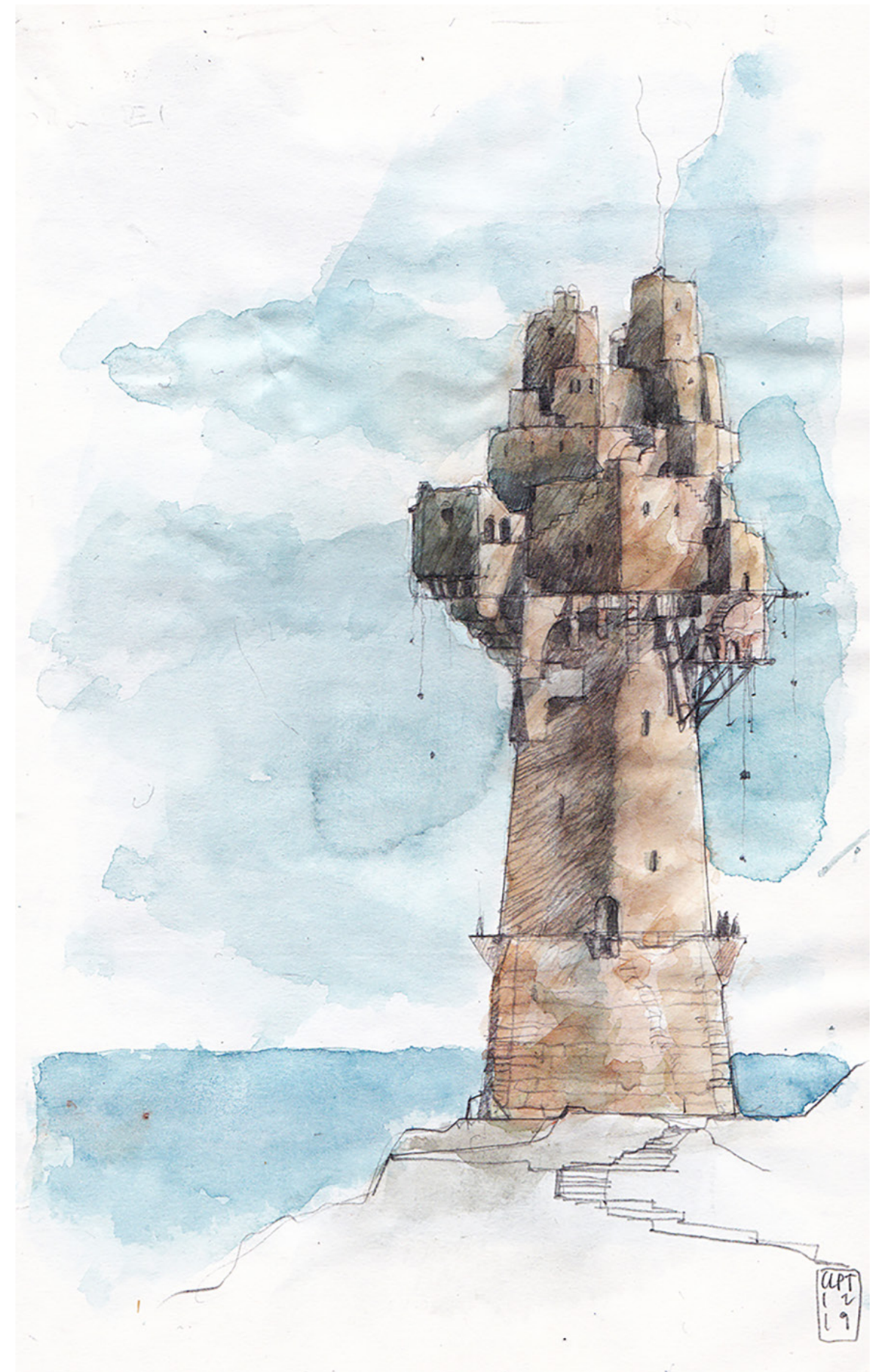




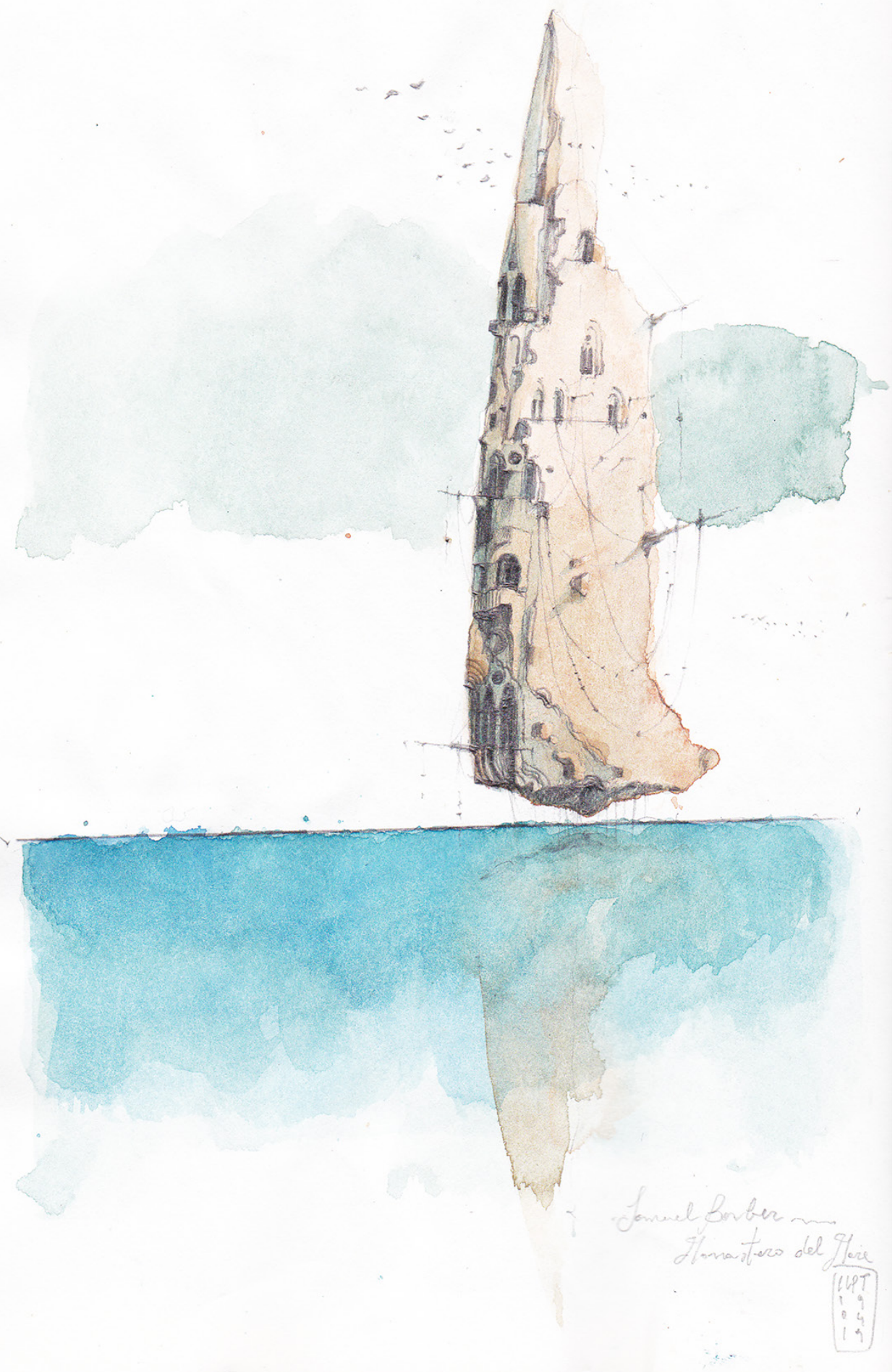




\section{Seasons and atmospheres in the drawing}

You have to know how to wait for the changing seasons, to wait for the change of techniques and tools to be used. The atmosphere and the places crossed will be the guide to the body of the draughtsman who incessantly seeks answers from what he sees. The paper will adapt to the humidity and dryness of the climate. Chalk, charcoal, red crayon, graphite, pastels like dust will build the architecture and turreted cities, portraits and nude self-portraits from which to discover and read on a long winter night. Large sheets of paper will replace the small diary, for a need for real appearances. Icarus flew too high to capture the shadow of the sun and fell, but he remains suspended, on white sheets of paper so that he doesn't disappear and die at sea (fig. 9). The winter season makes the draughtsman bend on himself, dredging from the bottom of his mind and his memory, remains at his table and listens: fantasies, inventions, visible, visions, maps drawn from the traces and buzzes of his body. He is enchanted by the night, when he indulges in black and sepia-coloured inks. The beaches are deserted, just as the sea turns grey and overturns the idea of light-coloured skies, with low clouds in the distance rarefied by rain. A concrete city slowly shatters as a gust of wind passes (fig. I0), a cloud stands still isolated in a grey sky, a woman stands still in front of the sea on her balcony in August '43, an airplane German flies over the east coast of Sicily, a walking stick lies between the rocks abandoned. Someone has taken to sea and never returned to shore.

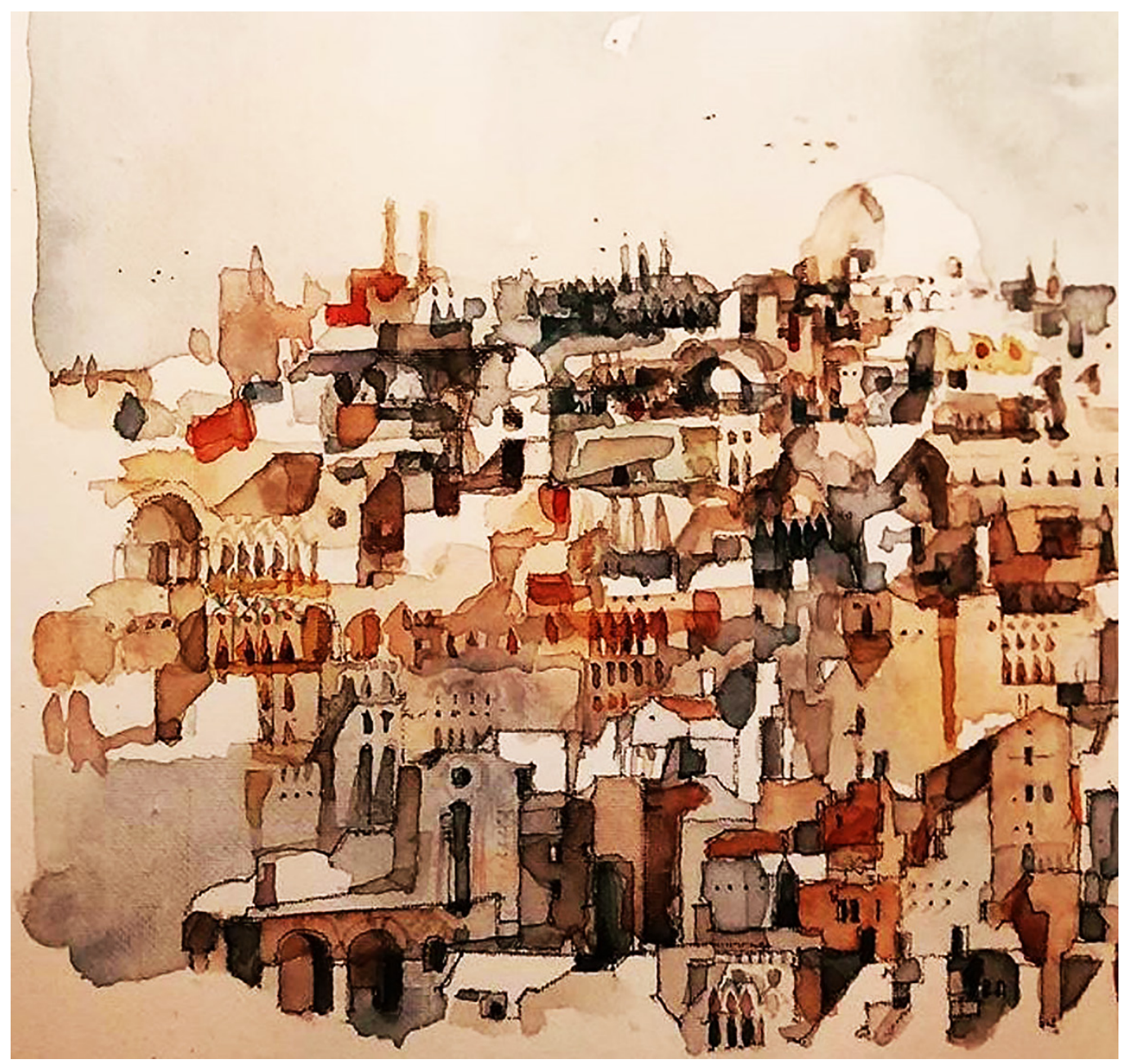


Fig. 9. Claudio Patanè, the author's studio. On the studio walls for lcarus elsewhere. Big cardboard. Charcoal and graphite on paper, 2019.
The time of colour is the time of rapture, of the "bright, clear and pure" eye. "If the eye were not sunny, it could never look into the sun. The eye owes its existence to light; thus the eye was formed by light for light, so that the inner light could meet the outer one" [Goethe in Di Napoli 2004, p. 513]. The light is that of the Mediterranean, of its spring and summer atmosphere, in contrast is the 'lutto' [Bufalino 1997]. A glimpse between houses abandoned by the intense ones, made of ancient lava stone, gives a glimpse of the lonian Sea and down at the bottom the light jump of Ibleo and Siracusa. (fig. I 2)

You surrender to the atmosphere of the strait between Sicily and Calabria, trying to find the time left for the water drawing, made of sultriness and summer heat, the time of the fluid state, equoreo, mixture of sirocco and salt that remains attached to the lenses of glasses and hands. Ships circulate, (fig. I I) following the moving horizon line through the windows of the hydrofoil. Two strips of ancient land are compared, difficult to define which is the island. The boat is swinging, the hand and the brush follow its swaying, the horizon between sea and sky accumulate on the paper holding back the reflections of the last lights on the west and the rising scirocco.

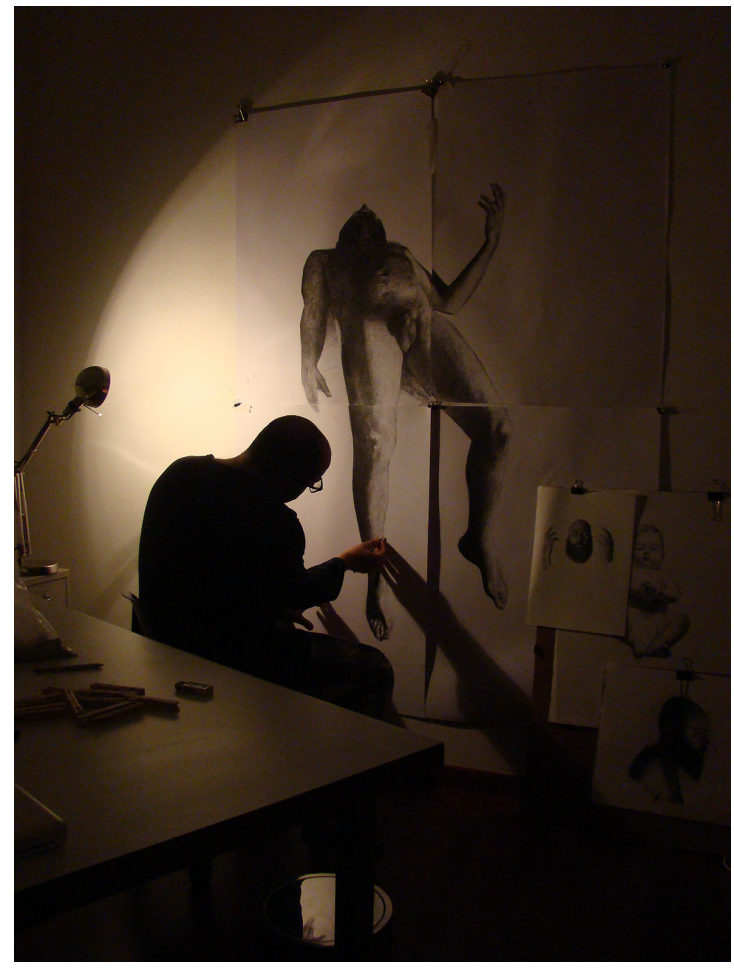

\section{Verify uncertain. What's left of the world in a small dimension, a diary}

The drawing on a notebook does not admit any conclusion, it tends to be unfinished, to leave the "registry" of what is looked at and known of the world around us in suspense. Minute its size, the diary, forces us to draw in a small, fragile and essential, compulsive, uncertain form. And for this reason it tends to disperse and not to recognize itself as a work. If not as a palimpsest work born posthumous in which life replaces the becoming of an aesthetic and artistic research. As in Alberto Giacometti's first small 'archaic' sculptures, in which the artist subtracted weight from the material, through the gestural tension of his hands to the haptic prehension, he reduced the size and plasticity of his primordial work to 'minimal terms'. Almost an act of protection and containment in his hands until reaching a small, spurious dimension, corroded by the space that contained it. Dimensions dispersed, caducous, without trace left. The same in a graphic diary: sketches, notes of an infinite, dirty speech, with himself to be discarded to start again. A constraint governed by primordial and archaic impulsive 


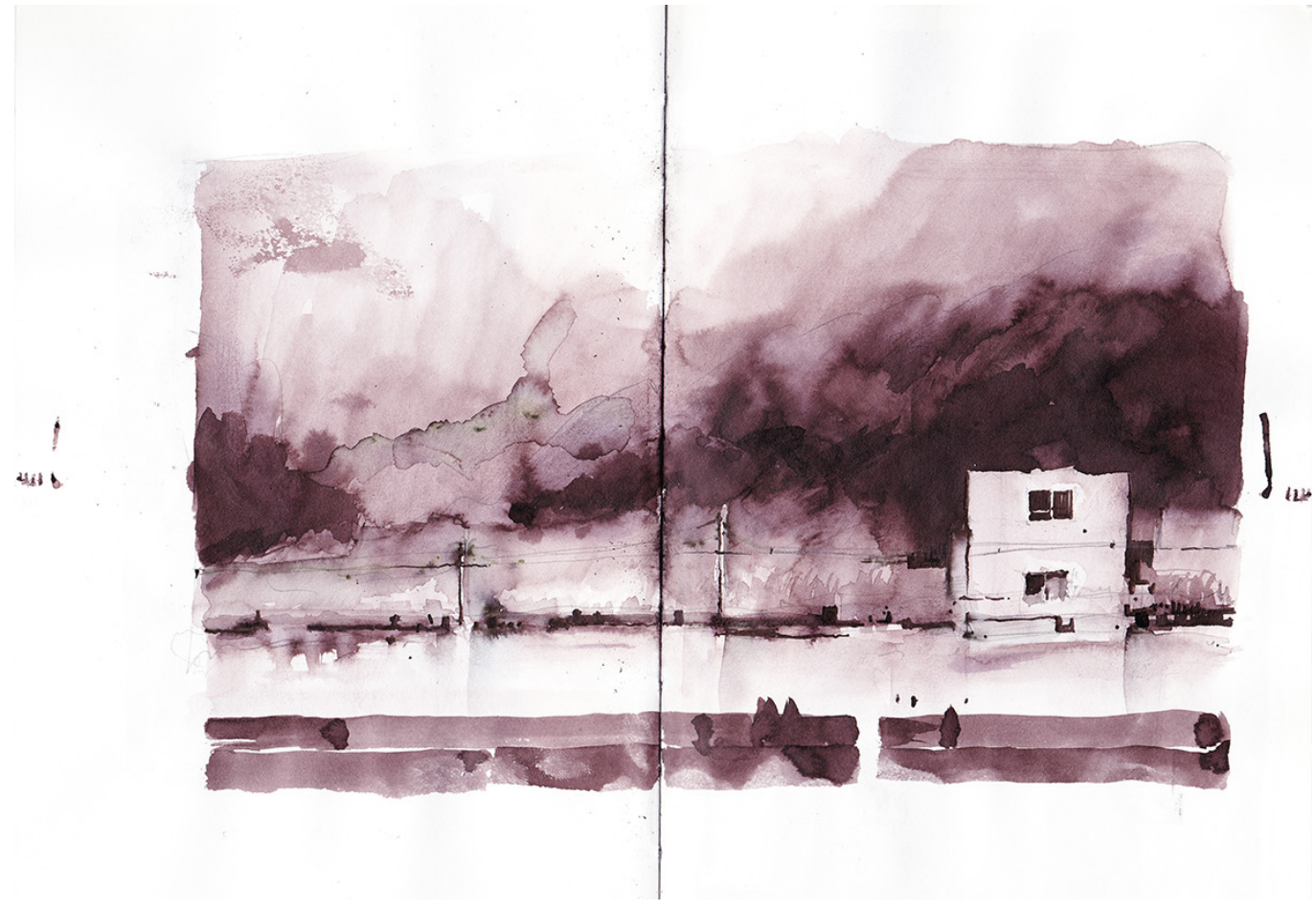

attempts. This intimate, occult dissemination, in which the author speaks with himself, hides and guards, is found as a sensory and emotional radiance in Leonardo's immense Codex Atlanticus, in Le Corbusier's Carnet de voyage (they are treatises on architecture), in Massimo Scolari's meticulous 48 watercolours ( $4 \times 6 \mathrm{~cm}$ format) "elementary observations on nature and artifice for improper use", in music in Beethoven and Borodin's enigmatic last "small" string quartets. They are born posthumously at its birth, these works precisely because they are secret, timidly, listen, often watched only by a few close friends. Francesco Moschini in the introduction to the work "Acquerelli e Disegni 1965-1980" by Massimo Scolari will thus conclude his preamble: "And then it becomes more pressing the need that, beyond the more typically pictorial elements, an insistent and meticulous drawing accompanies almost as a counterpoint to the individual works of Scolari, until it becomes a verification of the already treated and proposed novelty on barely perceptible differences with respect to the acquisitions achieved. The drawing thus becomes an autonomous formulation with its own life. And his returns, his obsessions, seem to be recorded on those notebooks-breviaries to which Scolari seems to tie the most spaced reflections and the most minute notes only apparently always similar to themselves" [Moschini 1980, p. I4].

\section{References}

Agostino, Sant' (2000). Le Confessioni. Torino: Einaudi Gallimard. Traduzione di Carlo Carena.

Berger John (20 I4). Il taccuino di Bento.Vicenza: Neri Pozza Editore. Traduzione di Maria Nadotti.

Berger John (20 I7). Sul disegnare. Milano: II Saggiatore. Traduzione di Maria Nadottt.

Berger John (2017). Confabulazioni.Vicenza: Neri Pozza Editore. Traduzione di Maria Nadotti.

Bufalino Gesualdo (1997). La luce e il lutto. Roma: Editori Riuniti.

Debord Guy (1956). Théorie de la dérive. Bruxelles: n. 9. (Ripubblicato senza le due appendici in Intenationale Situationniste, n. 2, dicembre 1958, Parigi.Trad.it. Internazionale Situazionista, Nautilus, Torino).

Di Napoli Giuseppe (2004). Disegnare e conoscere. La mano, l'occhio, il segno. Torino: Piccola Biblioteca Einaudi.

Edwards Betty (2002). Il nuovo Disegnare con la parte destra del cervello. Milano: Longanesi Edizioni. 

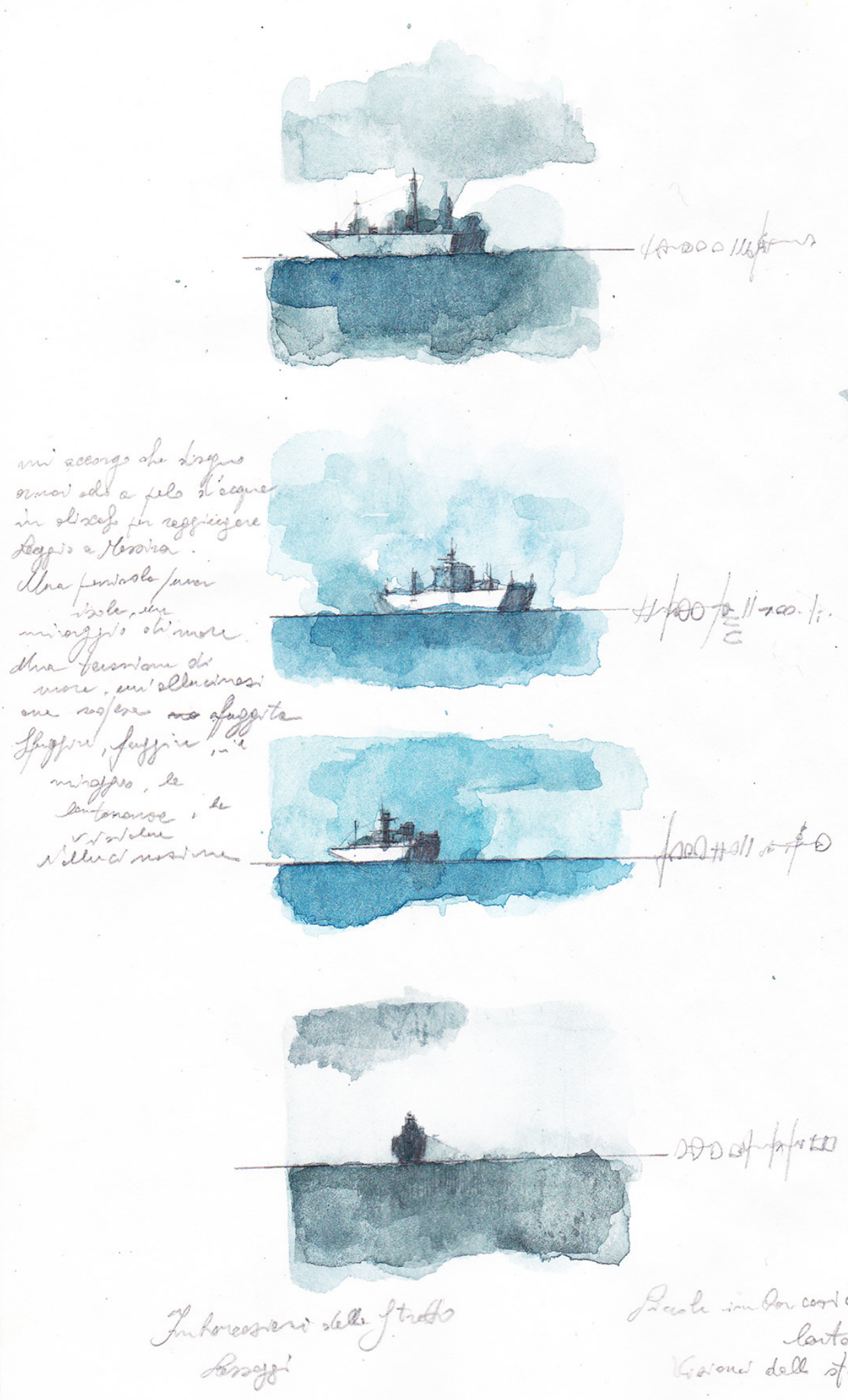

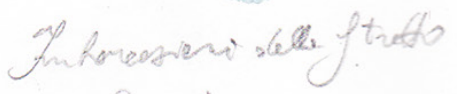

$$
\begin{aligned}
& \text { seroge' }
\end{aligned}
$$

$$
\begin{aligned}
& \text { Preale in lon cortiont in } \\
& \text { Givones dell sotwts apt }
\end{aligned}
$$


Fig. 12. Claudio Patanè Travel diary of the autor: On the page The lonian through", watercolour on paper, 2019

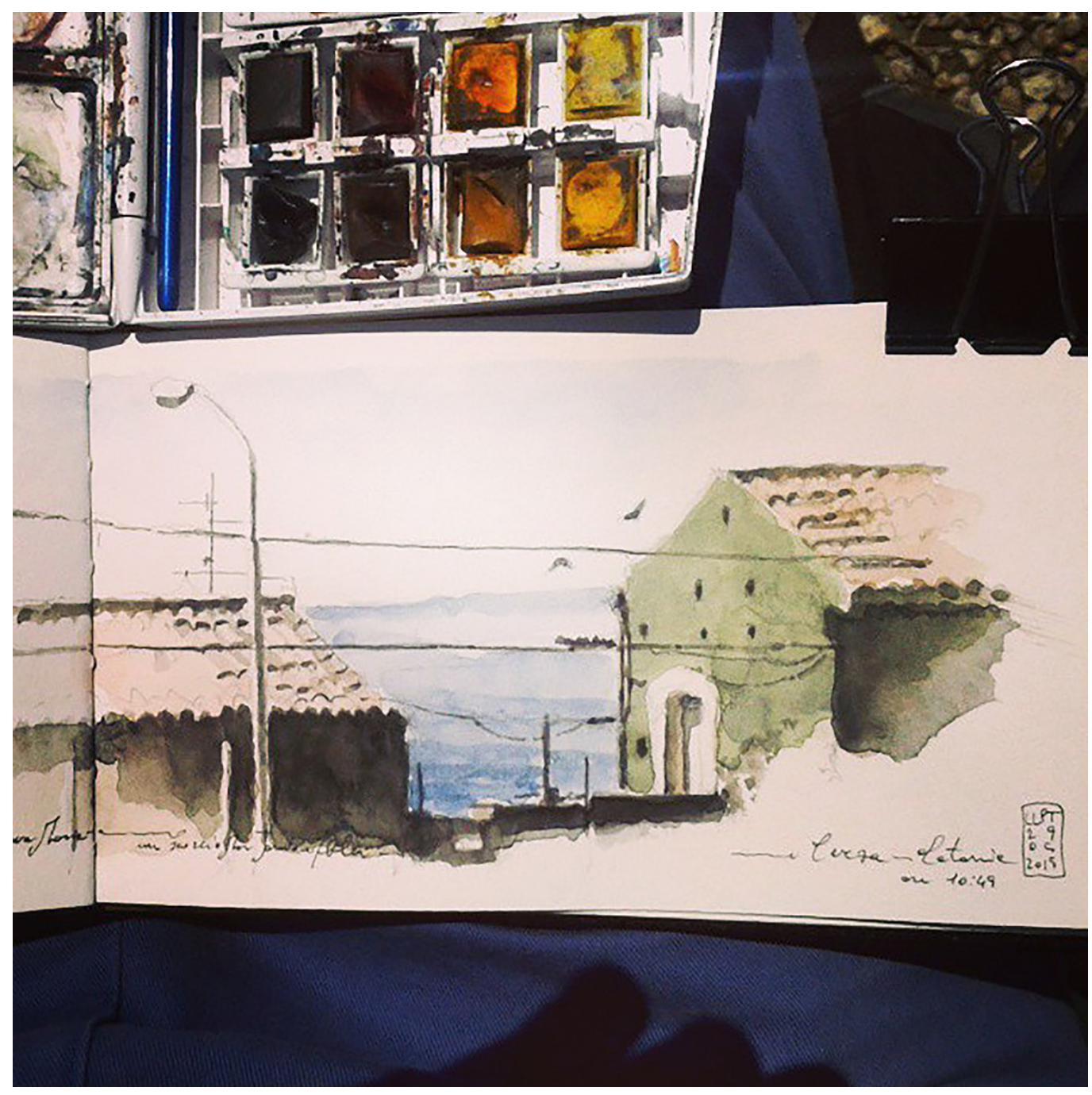

Foti Fabrizio (2016). La via del disegno. Siracusa: Lettera Ventidue Edizioni.

Kafka Franz (2004). Aforismi di Zürau. Milano: Piccola Biblioteca Adelphi.

Kehlmann Daniel (20|4). La misura del mondo. Milano: Feltrinelli. Traduzione di Paola Olivieri.

Moschini Francesco (1980). Massimo Scolari. Aquerelli e disegni 1965-1980. Firenze: ed. Centro Di.

Patanè Claudio (2018). Orizzonti nella mente. In Suq. Unconventional Sicily \#0, pp. 58-75.

Perec George (1994). L'infra-ordinario. Torino: Bollati Boringheri. (Traduzione di Roberta Delbono).

Rosa Ugo (2002). Dei disegni ultimi (su Mario Ridolfi). In Arch'it (FILES), I 3 febbraio 2002, p. I

Author

Claudio Patanè, Università degli Studi Mediterranea Reggio Calabria, claudio.patane@unirc.it

To cite this chapter. Patanè Claudio (2020). 'Custodiari' del tempo. II corpo, il viaggio, il disegno/'Custodiari' in the time. The body, the travel, the drawing. In Arena A., Arena M., Brandolino R.G., Colistra D., Ginex G., Mediati D., Nucifora S., Raffa P. (a cura di). Connettere. Un disegno per annodare e tessere. Atti del $42^{\circ}$ Convegno Internazionale dei Docenti delle Discipline della Rappresentazione/Connecting. Drawing for weaving relationships. Proceedings of the 42th International Conference of Representation Disciplines Teachers. Milano: FrancoAngeli, pp. 3634-3659. 